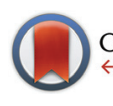

CrossMark $\leftarrow$ click for updates

Cite this: Dalton Trans., 2016, 45 4017

Received 15th December 2015, Accepted 25th January 2016

DOI: $10.1039 / \mathrm{c} 5 \mathrm{dt} 04885 \mathrm{k}$

www.rsc.org/dalton

\title{
Dinuclear ruthenium(II) complexes containing one inert metal centre and one coordinatively-labile metal centre: syntheses and biological activities
}

\author{
Xin Li, ${ }^{a}$ Kirsten Heimann, ${ }^{b, c}$ Fangfei Li, $\dagger^{a}$ Jeffrey M. Warner, ${ }^{c, d}$ F. Richard Keene ${ }^{\star c, e, f}$ \\ and J. Grant Collins*a
}

\begin{abstract}
A series of non-symmetric dinuclear polypyridylruthenium(॥) complexes (Rubb $\left.{ }_{n}-\mathrm{Cl}\right)$ that contain one inert metal centre and one coordinatively-labile metal centre, linked by the bis[4(4'-methyl-2,2'-bipyridyl)]$1, n$-alkane ligand ("bb $n$ " for $n=7,12$ and 16), have been synthesised and their potential as antimicrobial agents examined. The minimum inhibitory concentrations (MIC) of the ruthenium(॥) complexes were determined against four strains of bacteria - Gram-positive Staphylococcus aureus (S. aureus) and methicillin-resistant S. aureus (MRSA), and Gram-negative Escherichia coli (E. coli) and Pseudomonas aeruginosa ( $P$. aeruginosa). The Rubb $n-C l$ complexes displayed good antimicrobial activity, with $\mathrm{Rubb}_{12}-\mathrm{Cl}$ being the most active complex against both Gram-positive and Gram-negative strains. Interestingly, $\mathrm{Rubb}_{7}-\mathrm{Cl}$ was found to be eight- and sixteen-fold more active towards $E$. coli than against $S$. aureus and MRSA, respectively. The cytotoxicities of the $\mathrm{Rubb}_{n}-\mathrm{Cl}$ complexes against three eukaryotic cell lines two kidney cell lines (BHK and HEK-293) and one liver cell line (HepG2) - were examined. The Rubb ${ }_{n}-\mathrm{Cl}$ complexes were found to be considerably less toxic towards eukaryotic cells than S. aureus, MRSA and E. coli, with $\mathrm{Rubb}_{12}-\mathrm{Cl}$ being thirty- to eighty-times more toxic to the bacteria than to BHK, HEK-293 or HepG2 cells. Unexpectedly, Rubb $-\mathrm{Cl}$ was far more toxic to HepG2 cells ( $\left.24 \mathrm{~h}-\mathrm{IC}_{50}=3.7 \mu \mathrm{M}\right)$ and far less toxic to BHK cells $\left(24 \mathrm{~h}-\mathrm{IC}_{50}=238 \mu \mathrm{M}\right)$ than the Rubb $12-\mathrm{Cl}$ and Rubb $\mathrm{B}_{16}-\mathrm{Cl}$ complexes. In order to understand the unexpected large differences in the cytotoxicities of the Rubb ${ }_{n}-\mathrm{Cl}$ complexes towards eukaryotic cells, a confocal microscopic study of their intracellular localisation was undertaken. The results suggest that the observed cytotoxicity might be related to the extent of DNA binding.
\end{abstract}

\section{Introduction}

The emergence of drug-resistant populations of microorganisms has become a serious worldwide health issue. ${ }^{1}$ There is clearly a need for new antimicrobials; however more impor-

\footnotetext{
${ }^{a}$ School of Physical, Environmental and Mathematical Sciences, University of New South Wales, Australian Defence Force Academy, Canberra, ACT 2600, Australia. E-mail: g.collins@adfa.edu.au

${ }^{b}$ College of Marine \& Environmental Sciences, James Cook University, Townsville, QLD 4811, Australia

${ }^{c}$ Centre for Biodiscovery and Molecular Development of Therapeutics, James Cook University, Townsville, QLD 4811, Australia

${ }^{d}$ College of Public Health, Medical and Veterinary Sciences, James Cook University, Townsville, QLD 4811, Australia

${ }^{e}$ College of Science, Technology \& Engineering, James Cook University, Townsville, QLD 4811, Australia

${ }^{f_{S C h}}$ ool of Physical Sciences, University of Adelaide, Adelaide, SA 5005, Australia. E-mail:Richard.keene@adelaide.edu.au

$\dagger$ Current address: School of Chinese Medicine, Hong Kong Baptist University, Hong Kong, China.
}

tantly, new classes of antimicrobials are needed rather than drugs based upon analogues of known scaffolds.

Traditionally, the design and development of new antimicrobial drugs has centred upon organic chemistry. However, due to the success of cisplatin as an anticancer drug and the established ability of transition metal complexes to bind DNA and $\mathrm{RNA}^{2-6}$ there has been increasing interest in using metal complexes as antimicrobial agents. ${ }^{7-14}$ Among the transition metal complexes, ruthenium-based complexes have drawn increasing attention. ${ }^{9-14}$ Dwyer and co-workers were the first to report the biological activity of mononuclear tris(bidentate) inert polypyridyl metal complexes, in particular complexes with 1,10-phenanthroline ligands. ${ }^{9,10}\left[\mathrm{Ru}(\text { phen })_{3}\right]^{2+}$ was found to be inactive; however, the introduction of methyl substituents on the phen ligands dramatically increased the activity against all bacteria. ${ }^{9,10}$ More recently, it has been demonstrated that polypyridylruthenium(II) complexes which bind DNA by intercalation have significant bactericidal activity, particularly against Gram-positive strains. ${ }^{11,12}$ While DNA binding is generally thought to be responsible for the antimicrobial activity of 


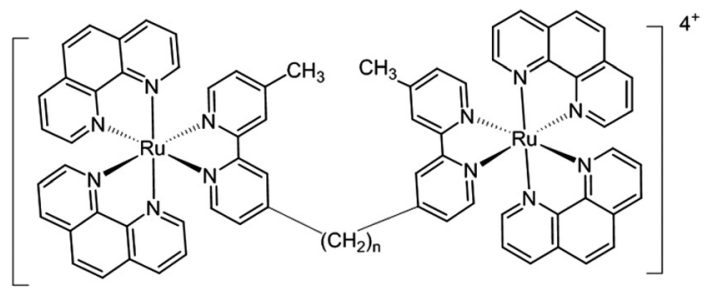

$\mathbf{R u b b}_{\mathrm{n}}$

Fig. 1 Structure of the Rubb $n$ complexes ( $n=7,12$ and 16).

polypyridylruthenium(II) complexes, Lam et al. suggested that the antimicrobial activity of a bis(bipyridine)ruthenium(II) complex containing a $N$-phenyl-substituted diazafluorene ligand might be due to DNA damage caused by the formation of reactive oxygen species. ${ }^{15}$ In addition, a range of labile ruthenium(II) and ruthenium(III) complexes have shown antimicrobial activity. ${ }^{16,17}$

We have recently demonstrated that dinuclear polypyridylruthenium(II) complexes containing a flexible bis[4(4'-methyl$\left(-2,2^{\prime}\right.$-bipyridyl)]-1,n-alkane $\left(\mathrm{bb}_{n}\right)$ bridging ligand (see Fig. 1) have good antimicrobial activity. ${ }^{18-21}$ These ruthenium complexes were highly active against a range of pathogenic bacteria, particularly Gram-positive strains,${ }^{18}$ and maintained the activity against drug-resistant bacteria, including strains that are of considerable current concern, e.g. methicillin-resistant Staphylococcus aureus (MRSA) and vancomycin-resistant Enterococcus (VRE). Furthermore, preliminary toxicity experiments indicated the dinuclear $\mathrm{Rubb}_{n}$ complexes were significantly less toxic to eukaryotic cells. ${ }^{22,23}$ Based upon the good antimicrobial activity and cell selectivity of the Rubb ${ }_{n}$ complexes, corresponding tri- and tetra-nuclear inert ruthenium complexes were subsequently synthesised. ${ }^{24}$ These complexes generally showed better activities than the dinuclear analogues and were more active against Gram-positive species. ${ }^{24}$

In another approach, we have also examined the effects of incorporating labile chlorido groups into dinuclear ruthenium (II) complexes linked by the $\mathrm{bb}_{n}$ ligand, $\left[\left\{\mathrm{Ru}(\mathrm{tpy}) \mathrm{Cl}_{\}_{2}}\left\{\mu-\mathrm{bb}_{n}\right\}\right]^{2+}\right.$ (Cl-Rubb ${ }_{n}$-Cl; where tpy $=2,2^{\prime}: 6^{\prime}, 2^{\prime \prime}$-terpyridine) ${ }^{25}$ see Fig. 2. The symmetrical $\mathrm{Cl}-\mathrm{Rubb}_{n}$-Cl complexes showed good activity against both Gram-positive bacteria and Gram-negative species. However, incorporation of the chlorido groups did significantly affect the relative activities of the ruthenium complexes, compared to the corresponding inert $\mathrm{Rubb}_{n}$ complexes. Whereas the order of activities for the inert complexes was $\mathrm{Rubb}_{16} \geq \mathrm{Rubb}_{12}>\mathrm{Rubb}_{7}$, it was found that $\mathrm{Cl}-\mathrm{Rubb}_{12}-\mathrm{Cl}$ was

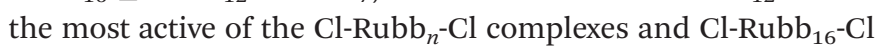
was slightly less active than the $\mathrm{Cl}_{-} \mathrm{Rubb}_{7}-\mathrm{Cl}$ complex. Taken together, the combined results highlight the balance between cationic charge and lipophilicity; however, it is not yet clear where the optimal charge/lipophilicity balance lies. In order to help clarify this issue, we aimed to synthesise and examine the antimicrobial activities of dinuclear ruthenium complexes that contained one inert metal centre and one metal centre that

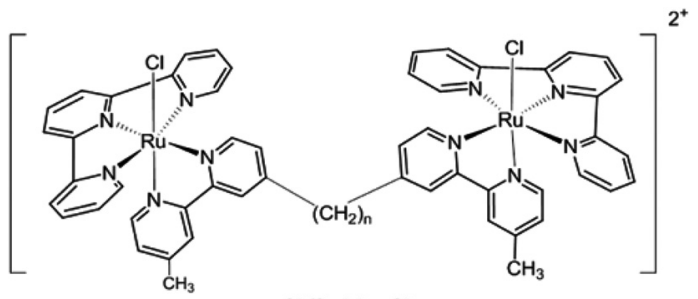

$\mathrm{Cl}^{-R u b b}-\mathrm{Cl}$

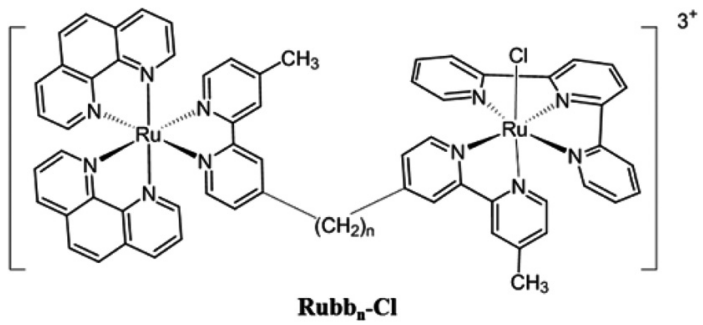

Fig. 2 Structures of the $\mathrm{Cl}-\mathrm{Rubb}_{n}-\mathrm{Cl}$ and the $\mathrm{Rubb}_{n}-\mathrm{Cl}$ complexes ( $n=$ 7, 12 and 16).

incorporated a chlorido ligand $\left(\mathrm{Rubb}_{n}{ }^{-\mathrm{Cl}}\right.$ complexes, see Fig. 2).

In this study, the synthesis and the antimicrobial properties of the non-symmetrical $\mathrm{Rubb}_{n}$-Cl complexes (for $n=7,12$ and 16) against Gram-positive S. aureus and MRSA, and Gramnegative Escherichia coli and Pseudomonas aeruginosa were examined. As the clinical potential of any new drug is determined by both the antimicrobial activity and the associated toxicity towards eukaryotic cells, the cytotoxicities of the $\mathrm{Rubb}_{n}$-Cl complexes against three eukaryotic cell lines were also examined. In order to understand the unexpected large differences in the cytotoxicities of the $\mathrm{Rubb}_{n}$-Cl complexes towards eukaryotic cells, a confocal microscopic study of their intracellular localisation was also undertaken.

\section{Experimental}

\section{Physical measurements and materials}

${ }^{1} \mathrm{H}$ NMR spectra were recorded on a Varian Unityplus $400 \mathrm{MHz}$ spectrometer with chemical shifts reported as $\delta$ values relative to the signal of tetramethylsilane. The NMR solvents $\mathrm{D}_{2} \mathrm{O}$ (99.9\%), $\mathrm{CD}_{2} \mathrm{Cl}_{2}$ (99.8\%), $\mathrm{CDCl}_{3}(99.8 \%), \mathrm{CD}_{3} \mathrm{CN}(99.8 \%)$ and ${ }^{\text {DMSO- }} \mathrm{d}_{6}(99.9 \%)$ were obtained from Cambridge Isotope Laboratories. Microanalyses were performed by the Microanalytical Unit, Research School of Chemistry, Australian National University. High-resolution mass spectral measurements were made using a Waters LCT mass spectrometer (Research School of Chemistry, Australian National University). 4,4'-Dimethyl2,2'-bipyridine ( $\mathrm{Me}_{2} \mathrm{bpy}$ ), lithium di-isopropylamide (LDA), 1,5dibromopentane, 1,10-dibromodecane, 1,14-dibromotetradecane, 2;2',6'; $2^{\prime \prime}$-terpyridine (tpy), and 1,10-phenanthroline (phen) were purchased from Sigma-Aldrich, and $\mathrm{RuCl}_{3} \cdot \mathrm{xH}_{2} \mathrm{O}$ from American Elements. For the nucleotides used, 5'-GMP (di-sodium salt) was obtained from Sigma-Aldrich while 5'-AMP, 5'-CMP and 5'-UMP (sodium salts) were from Apollo 
chemicals, Burlington, US. All chemicals were used as supplied.

The mononuclear ruthenium complex $\left[\mathrm{Ru}(\mathrm{tpy})\left(\mathrm{Me}_{2} \mathrm{bpy}\right) \mathrm{Cl}\right]$ $\mathrm{Cl}$ was synthesised as previously described. ${ }^{26}$ The synthesis of the bridging ligands $\mathrm{bb}_{n}(n=7,12$ and $16 ; \mathbf{A})$ were performed in a similar manner to that reported in the literature. ${ }^{27}$ The precursors $\left[\mathrm{Ru}(\mathrm{tpy}) \mathrm{Cl}_{3}\right] \quad$ (B) $\left[\mathrm{Ru}(\text { phen })_{2} \mathrm{Cl}_{2}\right] \mathrm{Cl} \quad$ (C), $\left[\mathrm{Ru}(\text { phen })_{2} \mathrm{Cl}_{2}\right](\mathbf{D}),\left[\mathrm{Ru}(\text { phen })_{2}(\mathrm{py})_{2}\right] \mathrm{Cl}_{2}(\mathbf{E}$; py $=$ pyridine $)$ and rac- $\left[\mathrm{Ru}(\mathrm{phen})_{2}\left(\mathrm{bb}_{n}\right)\right]\left(\mathrm{PF}_{6}\right)_{2} \quad(\mathbf{F})$ were prepared according to previously reported methods. ${ }^{27-29}$

\section{Synthesis of $\left[\mathrm{Ru}(\text { phen })_{2}\left(\mu-b_{b_{n}}\right) \operatorname{Ru}\left(t_{p y}\right) C l\right] \mathrm{Cl}_{3}\left(\operatorname{Rubb}_{n}-\mathrm{Cl}\right.$, $n=7,12$ and $16, \mathrm{G})$}

For $\left[\mathrm{Ru}(\text { phen })_{2}\left(\mu-\mathrm{bb}_{7}\right) \mathrm{Ru}(\mathrm{tpy}) \mathrm{Cl}\right] \mathrm{Cl}_{3}$, solid $\left[\mathrm{Ru}(\mathrm{tpy}) \mathrm{Cl}_{3}\right](10 \mathrm{mg}$, $0.032 \mathrm{mmol})$ and $\left[\mathrm{Ru}(\text { phen })_{2}\left(\mathrm{bb}_{7}\right)\right]\left(\mathrm{PF}_{6}\right)_{2}(3.7 \mathrm{mg}, 0.032 \mathrm{mmol})$ were refluxed in ethanol/water $(4: 1,10 \mathrm{~mL})$ for $3 \mathrm{~h}$. After cooling, excess $\mathrm{NH}_{4} \mathrm{PF}_{6}$ was added to precipitate a dark-brown material which was filtered and washed with ethanol. The crude product was then loaded onto a Sephadex LH20 sizeexclusion column and eluted with acetone. The $\left[\mathrm{Ru}(\text { phen })_{2}\left(\mu-\mathrm{bb}_{7}\right) \mathrm{Ru}(\mathrm{tpy}) \mathrm{Cl}\right]\left(\mathrm{PF}_{6}\right)_{3}$ fraction was obtained as the major dark-brown band which was isolated and evaporated to dryness. The $\mathrm{PF}_{6}{ }^{-}$salt was converted to the chloride (metathesis) by dissolving the solid in the minimum amount of acetone followed by the dropwise addition of a saturated solution of tetraethylammonium chloride in acetone with stirring for $30 \mathrm{~min}$. The resulting fluffy precipitate was centrifuged, decanted, washed several times with cold acetone and dried under reduced pressure to afford $\left[\mathrm{Ru}(\text { phen })_{2}\left(\mu-\mathrm{bb}_{7}\right) \mathrm{Ru}(\mathrm{tpy}) \mathrm{Cl}\right]$ $\mathrm{Cl}_{3}$ (yield $70-80 \%$ ). Separation of the possible geometric isomers (the chlorido ligand in the coordinatively-labile metal centre can potentially be either cis or trans to the pyridine ring of the $\mathrm{bb}_{n}$ ligand bearing the methyl group - the trans disposition is shown in Fig. 2) was not attempted.

$\left[\mathbf{R u}\left(\right.\right.$ phen $_{2}\left(\boldsymbol{\mu}-\mathbf{b b}_{7}\right) \mathbf{R u}($ tpy $\left.) \mathbf{C l}\right] \mathbf{C l}_{3} \quad\left(\mathbf{R u b b}_{7}-\mathbf{C l}\right) .{ }^{1} \mathrm{H} \quad \mathrm{NMR}$ $\left(\mathrm{CD}_{2} \mathrm{Cl}_{2}\right): \delta=10.09(\mathrm{~d}, J=6.2 \mathrm{~Hz}, 1 \mathrm{H}), 8.58(\mathrm{~d}, J=8.0 \mathrm{~Hz}, 2 \mathrm{H})$, $8.47(\mathrm{~d}, J=8.0 \mathrm{~Hz}, 2 \mathrm{H}), 8.30-8.38(\mathrm{~m}, 4 \mathrm{H}), 8.17-8.22(\mathrm{~m}, 8 \mathrm{H})$, $8.07(\mathrm{~s}, 1 \mathrm{H}), 8.00(\mathrm{t}, J=8.3 \mathrm{~Hz}, 1 \mathrm{H}), 7.79-7.88(\mathrm{~m}, 6 \mathrm{H}), 7.71(\mathrm{~d}$, $J=4.2 \mathrm{~Hz}, 1 \mathrm{H}), 7.61-7.66(\mathrm{~m}, 4 \mathrm{H}), 7.43-7.50(\mathrm{~m}, 2 \mathrm{H}), 7.23(\mathrm{t}$, $J=5.8 \mathrm{~Hz}, 2 \mathrm{H}), 7.13(\mathrm{~s}, 2 \mathrm{H}), 6.99(\mathrm{dd}, J=5.8,10.8 \mathrm{~Hz}, 1 \mathrm{H}), 6.75$ (s, 1H), $3.03(\mathrm{~s}, 1 \mathrm{H}), 2.86(\mathrm{~s}, 3 \mathrm{H}), 2.79(\mathrm{~s}, 2 \mathrm{H}), 2.56(\mathrm{~s}, 3 \mathrm{H}), 2.36$ (s, 2H), $2.12(\mathrm{~s}, 3 \mathrm{H}), 1.48-1.65(\mathrm{~m}, 10 \mathrm{H}) .{ }^{13} \mathrm{C} \mathrm{NMR}\left(\mathrm{CD}_{3} \mathrm{CN}\right)$ : $159.8,159.1$, 158.0, 156.8, 155.9, 153.6, 152.9, 152.2, 152.1, $152.0,151.4,149.8,149.0,148.9$, 148.7, 137.7, 137.6, 137.5, $134.1,131.9,129.0,127.8,127.0,125.7,125.4,124.8,124.6$, 124.5, 123.4, 35.8, 35.6, 35.5, 35.2, 31.0, 30.8, 30.8, 30.7, 29.7, 29.6, 29.5, 29.4, 21.3, 21.1, 20.8. TOF MS (ESI+): $m / z 442.7$ (for $\left.[\mathrm{M}-3 \mathrm{Cl}]^{3+}\right)$; calcd for $\mathrm{Ru}_{2}\left[\mathrm{C}_{68} \mathrm{H}_{59} \mathrm{~N}_{11} \mathrm{Cl}\right]^{3+}: \mathrm{m} / \mathrm{z} 442.6 ; \mathrm{m} / \mathrm{z}$ 651.6 (for $[\mathrm{M}-2 \mathrm{Cl}]^{2+}$ ); calcd for $\mathrm{Ru}_{2}\left[\mathrm{C}_{68} \mathrm{H}_{59} \mathrm{~N}_{11} \mathrm{Cl}_{2}\right]^{2+}: \mathrm{m} / \mathrm{z}$ 651.7; $m / z 1347.2$ (for [M]); calcd for $\mathrm{Ru}_{2}\left[\mathrm{C}_{68} \mathrm{H}_{59} \mathrm{~N}_{11} \mathrm{Cl}_{4}\right]: \mathrm{m} / \mathrm{z}$ 1374.2. Anal. Calcd for $\mathrm{C}_{68} \mathrm{H}_{59} \mathrm{ClF}_{18} \mathrm{~N}_{11} \mathrm{P}_{3} \mathrm{Ru}_{2} \quad\left\{\left[\mathrm{Ru}(\text { phen })_{2^{-}}\right.\right.$ $\left.\left.\left(\mu-b_{7}\right) \mathrm{Ru}(\mathrm{tpy}) \mathrm{Cl}\right]\left(\mathrm{PF}_{6}\right)_{3}\right\}: \mathrm{C}, 48.0 ; \mathrm{H}, 3.49 ; \mathrm{N}, 9.0 \%$. Found: C, 48.0; H, 3.52; N, 8.9\%.

$\left[\mathrm{Ru}(\text { phen })_{2}\left(\mu\right.\right.$-bb $\left.\left._{12}\right) \mathrm{Ru}(\mathrm{tpy}) \mathrm{Cl}\right] \mathrm{Cl}_{3}$ and $\left[\mathrm{Ru}(\text { phen })_{2}\left(\mu-\mathrm{bb}_{16}\right)-\right.$ $\mathrm{Ru}(\mathrm{tpy}) \mathrm{Cl}] \mathrm{Cl}_{3}$ were synthesised using an analogous procedure as that for $\left[\mathrm{Ru}(\text { phen })_{2}\left(\mu-\mathrm{bb}_{7}\right) \mathrm{Ru}(\mathrm{tpy}) \mathrm{Cl}\right] \mathrm{Cl}_{3}$ but with the appropriate $\mathrm{bb}_{n}$ bridging ligand.

$\left[\mathbf{R u}(\text { phen })_{2}\left(\boldsymbol{\mu}-\mathrm{bb}_{12}\right) \mathbf{R u}(\mathbf{t p y}) \mathbf{C l}\right] \mathrm{Cl}_{3} \quad\left(\mathrm{Rubb}_{12}-\mathrm{Cl}\right) .{ }^{1} \mathrm{H} \quad \mathrm{NMR}$ $\left(\mathrm{CD}_{2} \mathrm{Cl}_{2}\right): \delta=10.13(\mathrm{~d}, J=6.0 \mathrm{~Hz}, \mathrm{H}), 8.59(\mathrm{~d}, J=7.8 \mathrm{~Hz}, 2 \mathrm{H})$, 8.47 (d, $J=7.8 \mathrm{~Hz}, 2 \mathrm{H}), 8.34(\mathrm{~d}, J=7.8 \mathrm{~Hz}, 2 \mathrm{H}), 8.17-8.30(\mathrm{~m}$, $11 \mathrm{H}), 8.00-8.05(\mathrm{~m}, 2 \mathrm{H}), 7.83-7.90(\mathrm{~m}, 6 \mathrm{H}), 7.74(\mathrm{~d}, J=5.6 \mathrm{~Hz}$, $1 \mathrm{H}), 7.62-7.67(\mathrm{~m}, 4 \mathrm{H}), 7.50(\mathrm{~d}, J=5.6 \mathrm{~Hz}, 1 \mathrm{H}), 7.45(\mathrm{~m}, 1 \mathrm{H})$, $7.26(\mathrm{~m}, 2 \mathrm{H}), 7.15(\mathrm{~m}, 1 \mathrm{H}), 7.02(\mathrm{dd}, J=5.6,9.2 \mathrm{~Hz}, 1 \mathrm{H}), 6.77$ $(\mathrm{m}, 1 \mathrm{H}), 2.80(\mathrm{~s}, 3 \mathrm{H}), 2.68(\mathrm{~s}, 3 \mathrm{H}), 2.57(\mathrm{~s}, 2 \mathrm{H}), 2.42(\mathrm{~s}, 2 \mathrm{H})$, 1.20-1.68 (m, 20H). ${ }^{13} \mathrm{C}$ NMR ( $\left.\mathrm{CD}_{3} \mathrm{CN}\right): 159.7,159.1,157.9$, 156.7 , 155.8, 154.2, 153.6, 152.9, 152.6, 152.5, 152.2, 151.3, $148.9,148.6,137.7,137.6,137.5,134.1,131.9,129.0,128.3$, 128.1, 127.1, 126.9, 126.8, 126.1, 125.3, 124.4, 124.3, 123.4, $35.9,35.6,31.8,31.1,30.9,30.7,30.3,30.2,30.1,30.0,29.9$, 29.8, 29.6, 21.4, 21.1. TOF MS (ESI+): $\mathrm{m} / z 446.1$ (for [M $3 \mathrm{Cl}]^{3+}$ ); calcd for $\mathrm{Ru}_{2}\left[\mathrm{C}_{73} \mathrm{H}_{69} \mathrm{~N}_{11} \mathrm{Cl}\right]^{3+}: \mathrm{m} / \mathrm{z} 446.0 ; \mathrm{m} / \mathrm{z} 686.7$ (for $[\mathrm{M}-2 \mathrm{Cl}]^{2+}$ ); calcd for $\mathrm{Ru}_{2}\left[\mathrm{C}_{73} \mathrm{H}_{69} \mathrm{~N}_{11} \mathrm{Cl}_{2}\right]^{2+}: \mathrm{m} / z$ 686.7. Anal. Calcd for $\mathrm{C}_{73} \mathrm{H}_{77} \mathrm{O}_{4} \mathrm{Cl}_{4} \mathrm{~N}_{11} \mathrm{Ru}_{2}\left\{\left[\mathrm{Ru}(\text { phen })_{2}\left(\mu-\mathrm{bb}_{12}\right) \mathrm{Ru}(\mathrm{tpy}) \mathrm{Cl}\right]\right.$ $\left.(\mathrm{Cl})_{3} \cdot 4 \mathrm{H}_{2} \mathrm{O}\right\}: \mathrm{C}, 57.8 ; \mathrm{H}, 5.12 ; \mathrm{N}, 10.2 \%$. Found: C, 57.9; $\mathrm{H}$, $5.11 ; \mathrm{N}, 10.2 \%$.

$\left[\mathbf{R u}(\text { phen })_{2}\left(\boldsymbol{\mu}-\mathrm{bb}_{16}\right) \mathbf{R u}(\right.$ tpy $\left.) \mathbf{C l}\right] \mathrm{Cl}_{3} \quad\left(\mathrm{Rubb}_{16}-\mathrm{Cl}\right) .{ }^{1} \mathrm{H} \quad \mathrm{NMR}$ $\left(\mathrm{CD}_{2} \mathrm{Cl}_{2}\right): \delta=10.11(\mathrm{~d}, J=6.2 \mathrm{~Hz}, 1 \mathrm{H}), 8.57$ (d, $\left.J=7.4 \mathrm{~Hz}, 2 \mathrm{H}\right)$, 8.45 (d, $J=7.4 \mathrm{~Hz}, 2 \mathrm{H}), 8.32$ (d, $J=7.4 \mathrm{~Hz}, 2 \mathrm{H}), 8.13-8.25$ (m, $11 \mathrm{H}), 7.97-8.03(\mathrm{~m}, 2 \mathrm{H}), 7.81-7.87(\mathrm{~m}, 6 \mathrm{H}), 7.71(\mathrm{~d}, J=6.6 \mathrm{~Hz}$, $1 \mathrm{H}), 7.60-7.64(\mathrm{~m}, 4 \mathrm{H}), 7.47(\mathrm{~m}, 1 \mathrm{H}), 7.42(\mathrm{~d}, J=6.6 \mathrm{~Hz}, 1 \mathrm{H})$, $7.25(\mathrm{~m}, 2 \mathrm{H}), 7.14(\mathrm{t}, J=5.6 \mathrm{~Hz}, 2 \mathrm{H}), 7.00(\mathrm{t}, J=6.8 \mathrm{~Hz}, 1 \mathrm{H})$, $6.75(\mathrm{~m}, 1 \mathrm{H}), 2.78(\mathrm{~s}, 3 \mathrm{H}), 2.55(\mathrm{~s}, 3 \mathrm{H}), 2.35(\mathrm{~s}, 2 \mathrm{H}), 2.11(\mathrm{~s}$, $2 \mathrm{H}), 1.19-1.56(\mathrm{~m}, 28 \mathrm{H}) .{ }^{13} \mathrm{C}$ NMR $\left(\mathrm{CD}_{3} \mathrm{CN}\right):$ 159.7, 159.1, $157.9,156.7,155.7,153.6,153.5$, 152.9, 152.5, 152.3, 152.1, $151.3,149.7,148.9,148.9,148.6,137.7,137.6,137.5,134.2$, $131.9,129.0,128.3,128.1,127.9,127.1,126.9,126.8,126.0$, 125.2, 125.1, 125.0, 124.4, 124.3, 123.4, 35.9, 35.6, 35.3, 31.1, 30.8, 30.7, 30.3, 30.2, 30.2, 30.1, 30.0, 29.8, 29.6, 21.4, 21.7, 20.8. TOF MS (ESI+): $\mathrm{m} / z 464.8$ (for $[\mathrm{M}-3 \mathrm{Cl}]^{3+}$ ); calcd for $\mathrm{Ru}_{2}\left[\mathrm{C}_{77} \mathrm{H}_{77} \mathrm{~N}_{11} \mathrm{Cl}\right]^{3+}: \mathrm{m} / z$ 464.7; $m / z 714.7$ (for $[\mathrm{M}-2 \mathrm{Cl}]^{2+}$ ); calcd for $\mathrm{Ru}_{2}\left[\mathrm{C}_{77} \mathrm{H}_{77} \mathrm{~N}_{11} \mathrm{Cl}_{2}\right]^{2+}: m / z$ 714.8. Anal. Calcd for $\mathrm{C}_{77} \mathrm{H}_{77} \mathrm{ClF}_{18} \mathrm{~N}_{11} \mathrm{P}_{3} \mathrm{Ru}_{2} \quad\left\{\left[\mathrm{Ru}(\text { phen })_{2}\left(\mu-\mathrm{bb}_{16}\right) \mathrm{Ru}(\right.\right.$ tpy $\left.\left.) \mathrm{Cl}\right]\left(\mathrm{PF}_{6}\right)_{3}\right\}$ : C, 50.6; H, 4.24; N, 8.4\%. Found: C, 50.7; H, 4.42; N, 8.2\%.

$\Delta-\left[\mathrm{Ru}(\text { phen })_{2}\left(\mu-\mathrm{bb}_{n}\right) \mathrm{Ru}(\mathrm{tpy}) \mathrm{Cl}\right] \mathrm{Cl}_{3}$ complexes were synthesised following the same procedure as that for the racemic mixtures, using $\Delta-\left[\mathrm{Ru}(\text { phen })_{2}\left(\mathrm{bb}_{n}\right)\right]\left(\mathrm{PF}_{6}\right)_{2}(n=7,12$ and 16) as precursors. CD spectra: $\Delta-\mathrm{Rubb}_{7}-\mathrm{Cl}\left\{\lambda / \mathrm{nm}\left(\Delta \varepsilon / \mathrm{cm}^{-1} \mathbf{M}^{-1}\right)\right.$ $\left.\mathrm{H}_{2} \mathrm{O}\right\}$ : 290 (-374.3), 281 (-294.2), 272 (-405.1), 261 (469.3), 233 (27.3), 221 (77.5). $\Delta-\mathrm{Rubb}_{12}-\mathrm{Cl}\left\{\lambda / \mathrm{nm}\left(\Delta \varepsilon / \mathrm{cm}^{-1} \mathrm{M}^{-1}\right) \mathrm{H}_{2} \mathrm{O}\right\}$ : 290 (-356.7), 281 (-244.3), 271 (-352.3), 261 (412.8), 228 (10.5), 213 (107.4). $\Delta-\mathrm{Rubb}_{16}-\mathrm{Cl}\left\{\lambda / \mathrm{nm}\left(\Delta \varepsilon / \mathrm{cm}^{-1} \mathrm{M}^{-1}\right) \mathrm{H}_{2} \mathrm{O}\right\}$ : 288 (-364.4), 279 (-285.9), 271 (-358.7), 260 (393.6), 227 (39.2), 221 (80.5).

\section{Aquation of $\mathrm{Rubb}_{n}$-Cl complexes}

The ruthenium complexes $\left[\mathrm{Ru}(\mathrm{tpy})\left(\mathrm{Me}_{2} \mathrm{bpy}\right) \mathrm{Cl}\right] \mathrm{Cl}$ and $\Delta$-Rubb $b_{7}-\mathrm{Cl}$ were dissolved in $\mathrm{D}_{2} \mathrm{O}(650 \mu \mathrm{L})$ to give $1.0 \mathrm{mM}$ solutions. ${ }^{1} \mathrm{H}$ NMR spectra were then recorded as a function of time at $25{ }^{\circ} \mathrm{C}$. 


\section{Reaction of ruthenium complexes with nucleotides}

Reactions with nucleotides were carried out after the aquation of the chlorido-containing ruthenium complexes had reached equilibrium. The nucleotides 5'-GMP, 5'-AMP, 5'-CMP, and 5 '-UMP were dissolved in $\mathrm{D}_{2} \mathrm{O}$ and separately added to the ruthenium complexes $(1 \mathrm{mM})$ dissolved in $\mathrm{D}_{2} \mathrm{O}$ at the desired [Ru complex]:[nucleotide] ratio. ${ }^{1} \mathrm{H}$ NMR spectra were recorded as a function of time after mixing the sample thoroughly. NOESY experiments were conducted using the method of States et al. ${ }^{30}$ with 1024 data points in $t 2$ for $256 t 1$ values, a pulse repetition delay set to $1.5 \mathrm{~s}$ and mixing times from 100 to $500 \mathrm{~ms}$. Correlation spectroscopy experiments (DQFCOSY) were recorded using the same $t 1, t 2$ and pulse repetition values.

Molecular modelling was performed using HyperChem. ${ }^{31}$ Energy minimisation by Polak-Ribiere conjugate-gradient refinement was carried out with the metal complex treated as a rigid group. The ruthenium complex was manually docked to the GMP to reflect observed intermolecular NOEs.

\section{Bacterial strains}

Note: the bacterial strains used in this study are classified as risk group 2 according to the Australian/New Zealand Standard (AS/NZS 2243.4:2010) and accordingly were manipulated in a PC2 class laboratory. Gram-positive isolates a methicillin-susceptible $S$. aureus strain (ATCC 25923) and a clinical, multidrug-resistant, MRSA strain (JCU culture collection)\}, and two Gram-negative isolates $\{E$. coli (ATCC 25922) and $P$. aeruginosa (ATCC 27853)\}, were used for antimicrobial studies.

\section{Determination of minimum inhibitory concentration (MIC)}

MIC values were determined in duplicate by standard microdilution methodology in $\mathrm{CAMHB},{ }^{32}$ using gentamicin as the positive control, as previously described..$^{18,19}$

\section{Determination of minimum bactericidal concentration (MBC)}

The MBC tests were performed in duplicate according to a standard microbiological techniques protocol, ${ }^{33}$ as previously described. $^{18,19}$

\section{Cell culture}

Two kidney cell lines $\{$ BHK (baby hamster kidney) and HEK-293 (embryonic kidney)\}, and one liver cell line $\{$ HepG2 (liver carcinoma)\} were used in this study. All cell lines were generously supplied by the Australian Army Malaria Institute (AMI, Enoggera, QLD, Australia), and originated from the American Type Culture Collection (ATCC, Manassas, USA). Cells were cultured as previously described. ${ }^{22}$ Cells used in the study were in the logarithmic growth phase and were grown to $70 \%$ confluence, and then trypsinised with $0.25 \%$ trypsin$0.02 \%$ EDTA (Sigma-Aldrich) for detachment and used in the assays described below.
Half-maximal inhibitory concentration $\left(\mathrm{IC}_{50}\right)$ cytotoxicity assay

Half-maximal inhibitory concentrations $\left(\mathrm{IC}_{50}\right)$ of the ruthenium complexes were assessed using the Alamar Blue cytotoxicity assay (Invitrogen, Carlsbad, USA) as previously described. $^{22,34}$

\section{Cellular localisation of the ruthenium complexes}

Trypsinised HepG2 or BHK cells were seeded in Lumox® multiwell plates (Sarstedt, Numbrecht, Germany), and incubated with 5 to $100 \mu \mathrm{M}$ ruthenium complexes at $37{ }^{\circ} \mathrm{C}$ with $5 \% \mathrm{CO}_{2}$ for $20 \mathrm{~h}$. Following incubation, cells were stained with $100 \mathrm{nM}$ Mitotracker® Green FM (Invitrogen, Carlsbad, USA) for mitochondrial staining, $100 \mathrm{nM}$ DAPI (4',6-diamidino-2-phenylindole; Invitrogen) for nuclear staining and/or $50 \mathrm{nM}$ SYTO 9 (Invitrogen) for nucleolus staining. Staining was carried out in RPMI-1640 medium under standard cultivation conditions as per the manufacture's instructions. Following staining, cells were gently rinsed with phosphate buffer solution (PBS; $\mathrm{pH}=$ 7.1) prior to confocal laser scanning microscopy.

The cellular localisation of the ruthenium complexes was determined using a Zeiss laser scanning confocal microscope (LSM 700, Carl Zeiss, Göttingen, Germany). Samples were viewed under a $63 \times$ oil immersion lens. The ruthenium complexes $\left(\lambda_{\mathrm{ex}}=450 \mathrm{~nm}, \lambda_{\mathrm{em}}=610 \mathrm{~nm}\right)$, Mitotracker Green FM $\left(\lambda_{\mathrm{ex}}=490 \mathrm{~nm}, \lambda_{\mathrm{em}}=516 \mathrm{~nm}\right)$ and SYTO $9\left(\lambda_{\mathrm{ex}}=486 \mathrm{~nm}, \lambda_{\mathrm{em}}=\right.$ $501 \mathrm{~nm})$ were excited using a blue argon laser $\left(\lambda_{\mathrm{ex}}=488 \mathrm{~nm}\right)$, and emissions were collected over the range 570-650 $\mathrm{nm}$ for the metal complexes, 470-550 $\mathrm{nm}$ for Mitotracker and 495-510 nm for SYTO 9. For DAPI excitation, a diode laser $\left(\lambda_{\text {ex }}=405 \mathrm{~nm}\right)$ was used and the emission detected at 430-500 nm. Image data acquisition and processing was performed using Zen software 2009 (Carl Zeiss).

\section{Results}

\section{Synthesis of $\operatorname{Rubb}_{n}$-Cl ( $n=7,12$ and 16) complexes}

The syntheses of the symmetric oligonuclear polypyridine ruthenium complexes $\mathrm{Rubb}_{n}, \mathrm{Tri}^{\mathrm{Rubb}}{ }_{n}, \mathrm{Tetra}^{\mathrm{Rubb}} \mathrm{b}_{n}$ and

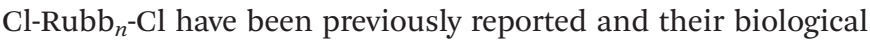
properties have been thoroughly studied. ${ }^{18-25}$ To obtain a better structure-activity relationship, a new class of nonsymmetric dinuclear ruthenium complexes $\mathrm{Rubb}_{n}-\mathrm{Cl}$ was designed and synthesised. The $\mathrm{Rubb}_{n}-\mathrm{Cl}$ complexes were prepared from $\left[\mathrm{Ru}(\text { phen })_{2}(\mathrm{py})_{2}\right]^{2+}(\mathbf{E}),\left[\mathrm{Ru}(\mathrm{tpy}) \mathrm{Cl}_{3}\right]$ (B) and the $\mathrm{bb}_{n}$ ligand (A) following the synthetic route shown in Scheme 1, with the final dinuclear product $\mathrm{Rubb}_{n}-\mathrm{Cl}$ (G) obtained through reaction of $\left[\mathrm{Ru}(\text { phen })_{2} \mathrm{bb}_{n}\right]^{2+}(\mathbf{F})$ with $\left[\mathrm{Ru}(\right.$ tpy $\left.) \mathrm{Cl}_{3}\right]$. $\left[\mathrm{Ru}(\text { phen })_{2}(\mathrm{py})_{2}\right]^{2+}$ and $\left[\mathrm{Ru}(\text { phen })_{2} \mathrm{bb}_{n}\right]^{2+}$ were purified by cation-exchange chromatography on an SP Sephadex C-25 column, whereas the final $\mathrm{Rubb}_{n}$-Cl complexes were purified by size-exclusion on a Sephadex $\mathrm{LH} 20$ column. The $\mathrm{Rubb}_{n}-\mathrm{Cl}$ complexes were characterised by ${ }^{1} \mathrm{H}$ and ${ }^{13} \mathrm{C}$ NMR, microanalysis and ESI-MS. 


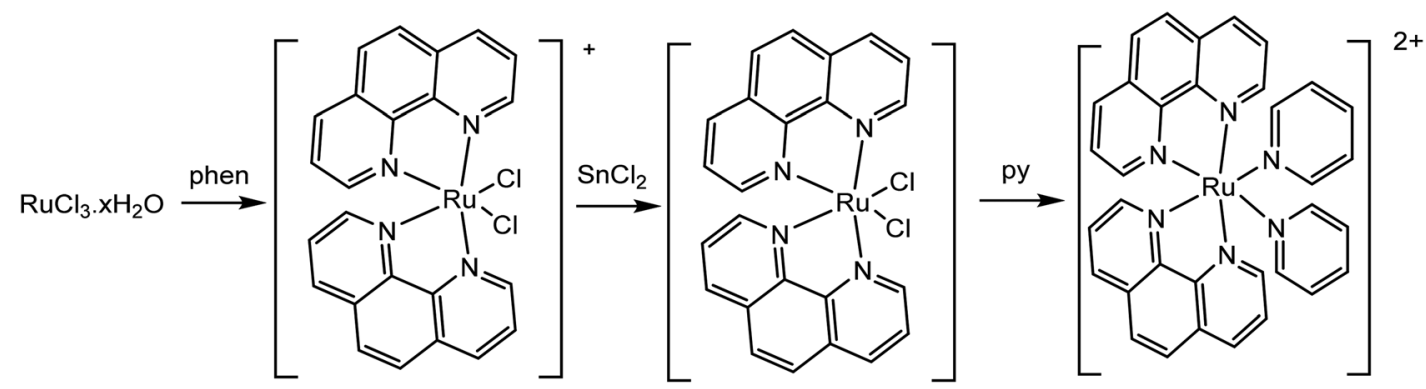

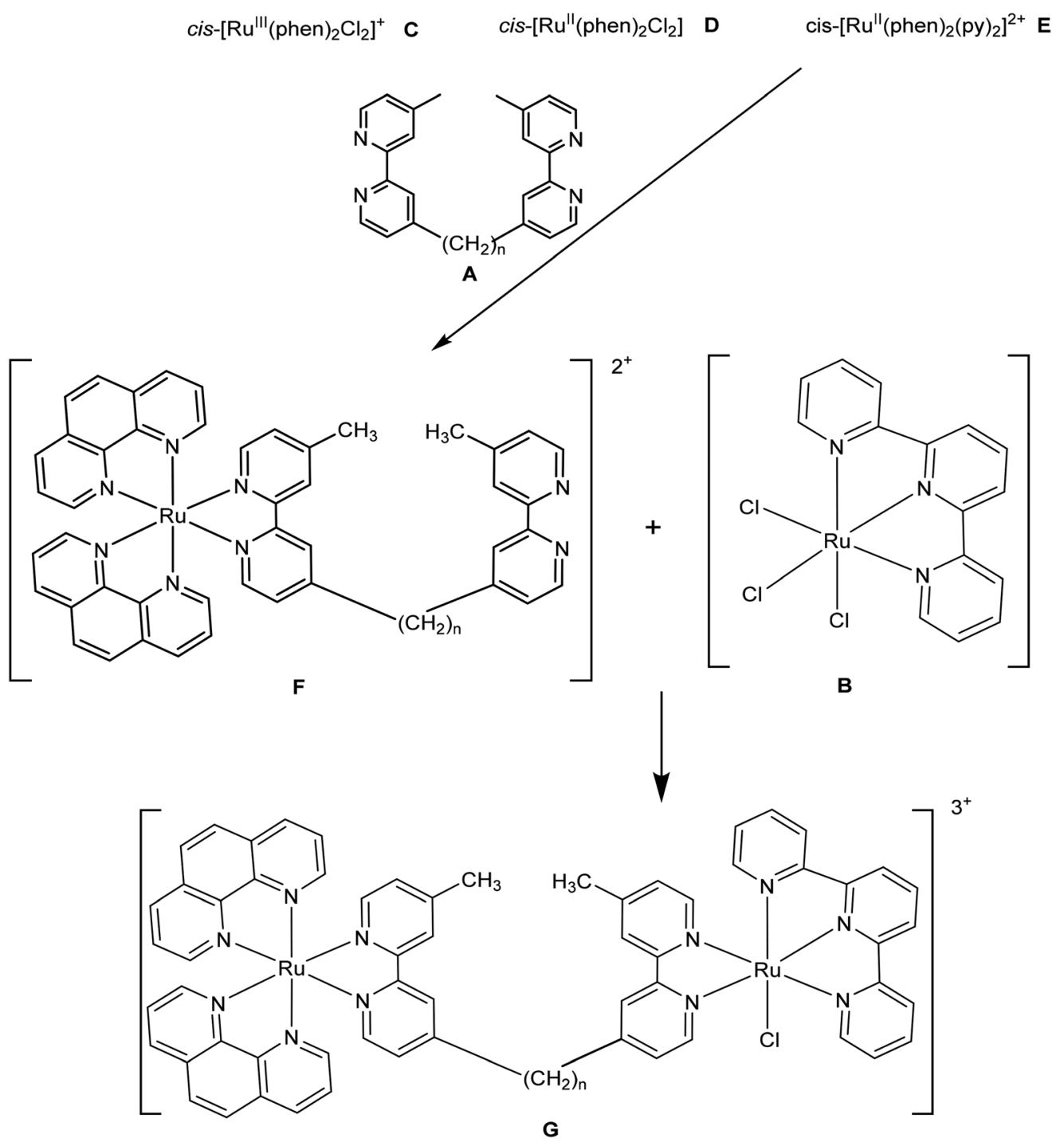

Scheme 1

\section{Aquation of chlorido-containing ruthenium complexes}

As the $\mathrm{Rubb}_{n}$-Cl complexes are activated towards covalent bond formation with intracellular targets by aquation, a study of the aquation of $\mathrm{Rubb}_{7}-\mathrm{Cl}$ and the parent complex [Ru(tpy)$\left.\left(\mathrm{Me}_{2} \mathrm{bpy}\right) \mathrm{Cl}\right]^{+}$was carried out. The rate of aquation of [ $\mathrm{Ru}(\mathrm{tpy})-$ $\left.\left(\mathrm{Me}_{2} \mathrm{bpy}\right) \mathrm{Cl}\right]^{+}$has been previously determined by ${ }^{1} \mathrm{H}$ NMR spectroscopy, ${ }^{26}$ where the concomitant disappearance of the resonance from the $\mathrm{H} 6$ of the $\mathrm{Me}_{2}$ bpy ligand from the chlorido complex and the emergence of the corresponding resonance from the aqua species were monitored as a function of time. By following the disappearance of the $\mathrm{H} 6$ resonance of the $\mathrm{Me}_{2}$ bpy ligand for $\left[\mathrm{Ru}(\mathrm{tpy})\left(\mathrm{Me}_{2} \mathrm{bpy}\right) \mathrm{Cl}\right]^{+}(9.71 \mathrm{ppm})$ and $\mathrm{Rubb}_{7}-\mathrm{Cl}(9.52 \mathrm{ppm})$ and the emergence of the corresponding resonance of the aqua complexes $(9.52$ and $9.24 \mathrm{ppm}$, respectively), it was determined that $50 \%$ aquation is achieved 
A

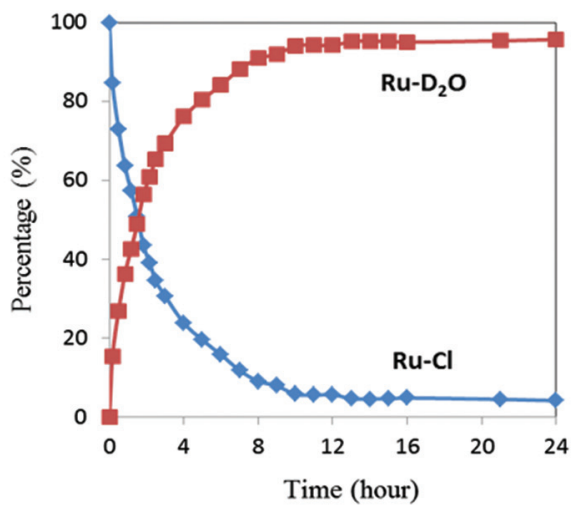

B

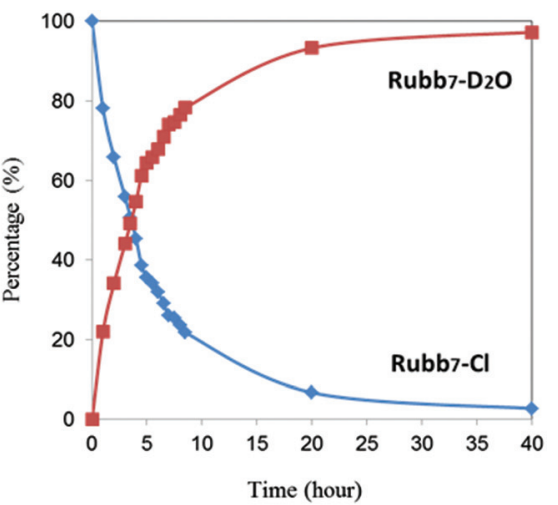

Fig. 3 (A) The relative proportions of $\left[R u(t p y)\left(\mathrm{Me}_{2} \text { bpy }\right) C l\right]^{+}$and $\left[R u(t p y)\left(\mathrm{Me}_{2} b p y\right)\left(\mathrm{D}_{2} \mathrm{O}\right)\right]^{2+}$ as a function of time after dissolving the chlorido species in $\mathrm{D}_{2} \mathrm{O}$; (B) the relative proportions of $\mathrm{Rubb}_{7}-\mathrm{Cl}$ and $\mathrm{Rubb}_{7}-\mathrm{D}_{2} \mathrm{O}$ as a function of time after dissolving the chlorido form in $\mathrm{D}_{2} \mathrm{O}$.

in 90 minutes for $\left[\mathrm{Ru}(\text { tpy })\left(\mathrm{Me}_{2} \mathrm{bpy}\right) \mathrm{Cl}\right]^{+}$and 210 minutes for Rubb-Cl (see Fig. 3).

\section{Reaction of $\left[\mathrm{Ru}(\mathrm{tpy})\left(\mathrm{Me}_{2} \mathrm{bpy}\right)\left(\mathrm{D}_{2} \mathrm{O}\right)\right]^{2+}$ with nucleotides}

The covalent binding of $\left[\mathrm{Ru}(\mathrm{tpy})\left(\mathrm{Me}_{2} \mathrm{bpy}\right)\left(\mathrm{D}_{2} \mathrm{O}\right)\right]^{2+}$ with each of the di-anions of guanosine monophosphate (5'-GMP), cytidine monophosphate (5'-CMP), adenosine monophosphate (5'-AMP) and uridine monophosphate (5'-UMP) was studied. After a 24-hour incubation of $\left[\mathrm{Ru}(\mathrm{tpy})\left(\mathrm{Me}_{2} \mathrm{bpy}\right)\left(\mathrm{D}_{2} \mathrm{O}\right)\right]^{2+}$ with each nucleotide, the ${ }^{1} \mathrm{H}$ NMR spectrum was recorded and the spectra are shown in Fig. 4. Addition of AMP, CMP and UMP to $\left[\mathrm{Ru}(\text { tpy })\left(\mathrm{Me}_{2} \mathrm{bpy}\right)\left(\mathrm{D}_{2} \mathrm{O}\right)\right]^{2+}$ only resulted in the slight broadening of the nucleotide resonances without the emergence of new peaks, suggesting a weak reversible association between the ruthenium complex and the nucleotides. However, 24 hours after the addition of GMP to [Ru(tpy)( $\left.\mathrm{Me}_{2} \mathrm{bpy}\right)-$ $\left.\left(\mathrm{D}_{2} \mathrm{O}\right)\right]^{2+}$ distinct differences in the NMR spectrum were observed. The absence of a resonance at $9.71 \mathrm{ppm}$ (H6 of $\mathrm{Me}_{2}$ bpy of the chlorido species) indicated that the equilibrium had shifted towards the aqua complex. Furthermore, a small second set of broad peaks emerged, indicating the formation of a covalently-bound adduct. Based upon the relative integrals of the sugar $\mathrm{H}^{\prime}$ of the free GMP $(5.90 \mathrm{ppm})$ and ruthenium complex-bound GMP (5.50 ppm), approximately $35 \%$ of the GMP covalently bound $\left[\mathrm{Ru}(\mathrm{tpy})\left(\mathrm{Me}_{2} \mathrm{bpy}\right)\left(\mathrm{D}_{2} \mathrm{O}\right)\right]^{2+}$ in 24 hours.

Given the observed preferential binding of $\left[\mathrm{Ru}(\mathrm{tpy})\left(\mathrm{Me}_{2} \mathrm{bpy}\right)-\right.$ $\left.\left(\mathrm{D}_{2} \mathrm{O}\right)\right]^{2+}$ with GMP, further studies were only carried out with GMP. Fig. 5 shows the ${ }^{1} \mathrm{H}$ NMR spectrum of [Ru(tpy)( $\mathrm{Me}_{2}$ bpy)$\left.\left(\mathrm{D}_{2} \mathrm{O}\right)\right]^{2+}$ with added GMP as a function of time, and after the addition of further GMP after 64 hours. The H8 of GMP was tentatively assigned by heating the sample at $50{ }^{\circ} \mathrm{C}$ for 16 hours. The H8 of GMP will slowly exchange with a deuterium in the $\mathrm{D}_{2} \mathrm{O}$ solvent at $50{ }^{\circ} \mathrm{C} ;$ e.g. see the reduction in intensity of the H8 of the free GMP in Fig. 5D and E. Consequently, the singlet resonance at $6.56 \mathrm{ppm}$ could be assigned to the $\mathrm{H} 8$ of bound GMP.

The assignment of the proton resonances from the $[\mathrm{Ru}(\mathrm{tpy})-$ $\left(\mathrm{Me}_{2}\right.$ bpy)GMP] adduct was determined from DQFCOSY and

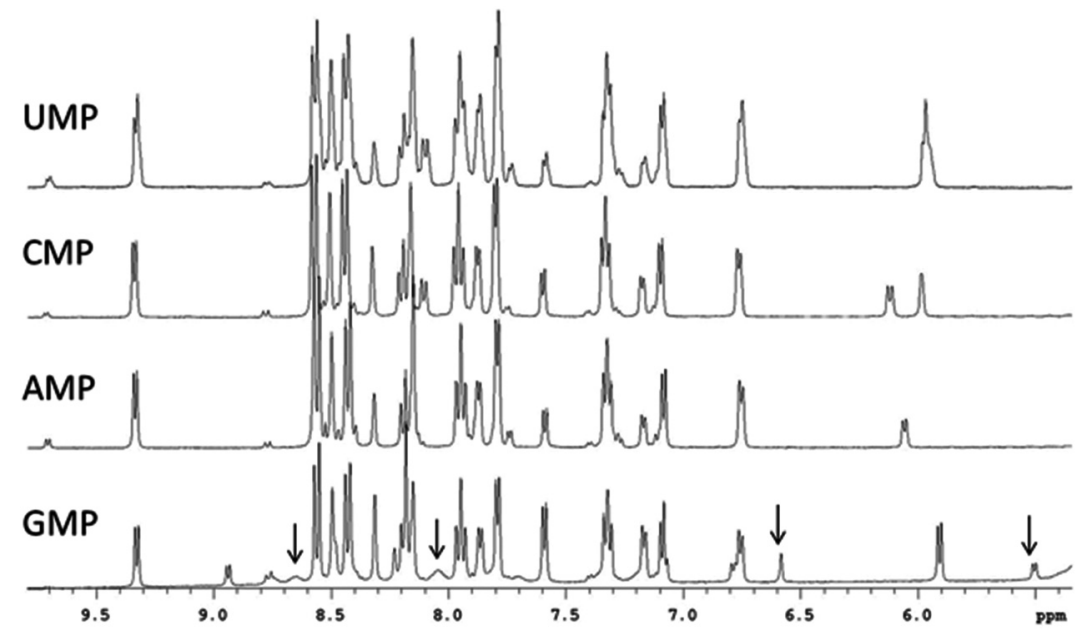

Fig. $4{ }^{1} \mathrm{H}$ NMR spectra of $\left[R u(t p y)\left(M_{2} b p y\right)\left(D_{2} O\right)\right]^{2+}$ and either UMP, CMP, AMP and GMP, at a ruthenium complex to nucleotide ratio of $2: 1$, in $D_{2} \mathrm{O}$ after a 24 hour incubation. In the spectrum of $\left[R u(t p y)\left(M_{2} b p y\right)\left(D_{2} O\right)\right]^{2+}$ with GMP the arrows indicate the new peaks due to the covalent adduct. 


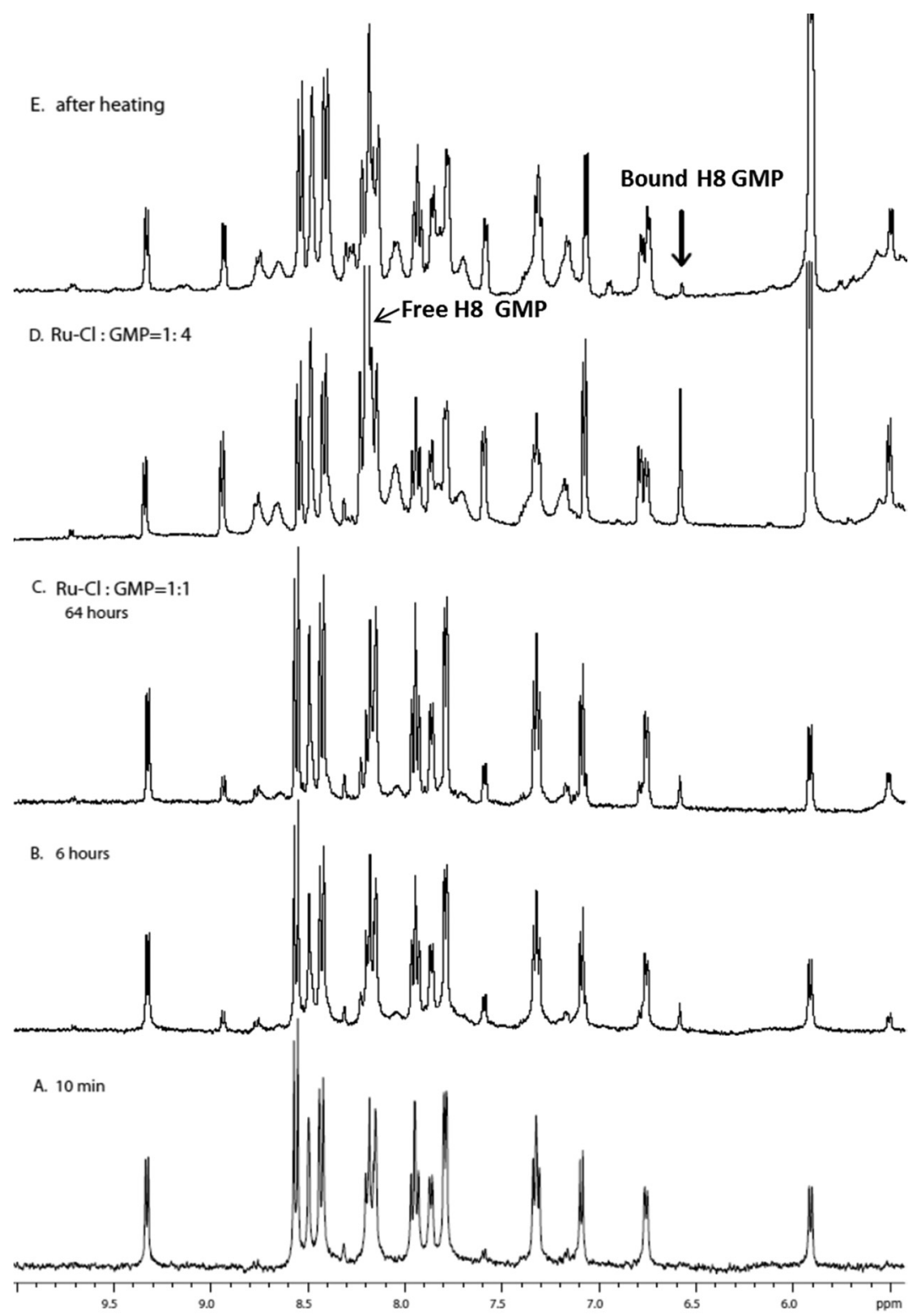

Fig. $5{ }^{1} \mathrm{H}$ NMR spectra of the reaction between $\left[R u(t p y)\left(M e_{2} b p y\right)\left(D_{2} O\right)\right]^{2+}$ and GMP. $A, B$ and $C$ are time-course experiments with the $[R u]:[G M P]=$ $1: 1$ at $25^{\circ} \mathrm{C}$ at 10 minutes, 6 hours and 64 hours after starting the reaction, respectively; D after the addition of three more equivalents of GMP to give a $[R u]:[G M P]=1: 4$; $E$ spectrum after $\mathrm{D}$ was heated at $50^{\circ} \mathrm{C}$ for 16 hours, black arrow indicates $\mathrm{GH} 8$ in the bound adduct.

NOESY spectra (data not shown). In the NOESY spectrum of the aromatic to sugar $\mathrm{H}_{1}^{\prime}$ region, strong NOE cross peaks were observed between the tpy H6 and H6", H5 and H5", H4 and $\mathrm{H} 4{ }^{\prime \prime}, \mathrm{H} 3$ and $\mathrm{H}^{\prime \prime}$ and $\mathrm{H}^{\prime}$ ' and $\mathrm{H}^{\prime}$, indicating the tpy protons were in slow exchange (on the NMR time scale) between two forms. Due to rotation around the Ru-N7 bond, it is possible that $\left[\mathrm{Ru}(\mathrm{tpy})\left(\mathrm{Me}_{2} \mathrm{bpy}\right) \mathrm{GMP}\right]$ complex may exist in two conformers that are in slow exchange. An NOE cross peak between the $\mathrm{H} 8$ and sugar $\mathrm{H}^{\prime}$ ' of the bound GMP at 6.56/5.50 ppm provided further support for the assignment of the $\mathrm{H} 8$ of the bound GMP. Based on the NMR analysis, the binding site of ruthenium complex is most likely at the N7 of the GMP, given the large shift observed for the GH8 resonance.
A molecular model of the ruthenium complex-GMP adduct is shown in Fig. 6. In the model, the GMP H8 is positioned directly below the tpy aromatic rings, which may explain the unusual upfield shift observed for the resonance upon N7-metallation.

The time-course ${ }^{1} \mathrm{H}$ NMR spectra of the reaction between the dinuclear complex $\mathrm{Rubb}_{7}-\mathrm{Cl}$ and GMP also showed the emergence of resonances for the ruthenium complex-GMP adduct (data not shown). A singlet at $6.65 \mathrm{ppm}$ could be assigned to the H8 from bound GMP, and new broad peaks in the 8.7-8.9 ppm region were possibly from the bound metal complex. These observations were similar to those from the reaction between $\left[\mathrm{Ru}(\mathrm{tpy})\left(\mathrm{Me}_{2} \mathrm{bpy}\right) \mathrm{Cl}\right]^{+}$and $\mathrm{GMP}$, described 


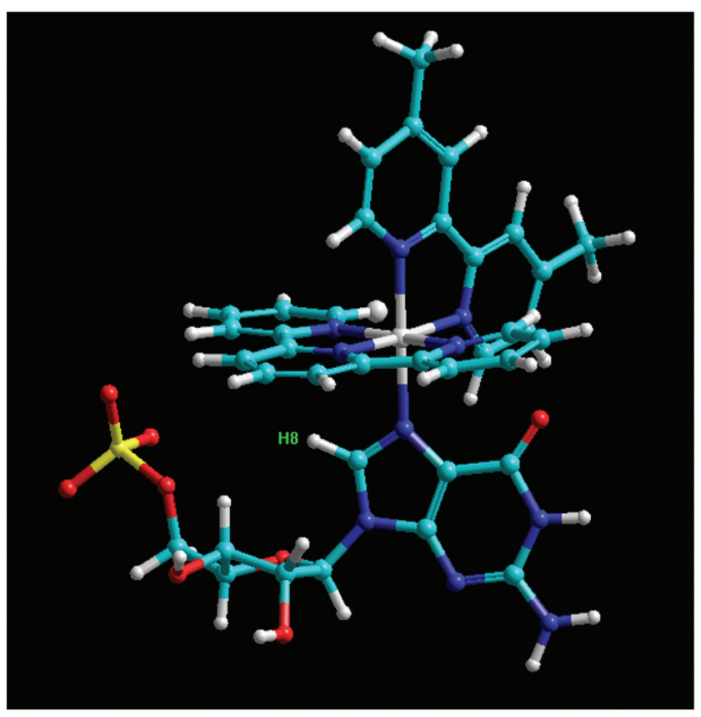

Fig. 6 A molecular model of [Ru(tpy)(Me ${ }_{2}$ bpy)GMP].

above, suggesting that $\mathrm{Rubb}_{7}-\mathrm{Cl}$ interacts with GMP by forming a covalent bond.

\section{Antimicrobial activity}

The minimum inhibitory concentration (MIC) and minimum bactericidal concentration (MBC) values for the $\mathrm{Rubb}_{n}-\mathrm{Cl}$ complexes against $S$. aureus, MRSA, E. coli and P. aeruginosa were determined and are summarised in Table 1 . All Rubb ${ }_{n}-\mathrm{Cl}$ complexes showed significant activity against both the Gram-negative and Gram-positive strains, with the Gram-negative strain $P$. aeruginosa being the least susceptible. Overall, $\mathrm{Rubb}_{12}-\mathrm{Cl}$ showed the best activity across the $\mathrm{Rubb}_{n}$-Cl series. Compared to $\mathrm{Rubb}_{12}-\mathrm{Cl}, \mathrm{Rubb}_{16}-\mathrm{Cl}$ was similarly active against the two Gram-positive strains, but showed considerably lower activity against the Gram-negative strains. On the other hand, $\mathrm{Rubb}_{7}-\mathrm{Cl}$ was less active than $\mathrm{Rubb}_{12}-\mathrm{Cl}$ against the Gram-positive strains, but equally as active as $\mathrm{Rubb}_{12}$ - $\mathrm{Cl}$ against the Gramnegative bacteria. As the MBC values were $\leq 2 \times \mathrm{MIC}$, it is concluded that all the $\mathrm{Rubb}_{n}$-Cl complexes are bactericidal, rather than bacteriostatic. The $\mathrm{Rubb}_{n}-\mathrm{Cl}$ complexes generally showed similar or better activity than the $\mathrm{Rubb}_{n}$ and $\mathrm{Cl}_{-\mathrm{Rubb}}-\mathrm{Cl}$ complexes, with $\mathrm{Rubb}_{12}-\mathrm{Cl}$ exhibiting as good an activity profile as any of the other previously-reported ruthenium complexes linked by the $\mathrm{bb}_{n}$ ligand, including the tri- and tetra-nuclear inert complexes. ${ }^{18,24}$

Over the four bacteria examined in this study, $\mathrm{Rubb}_{7}-\mathrm{Cl}$ and $\mathrm{Rubb}_{12}$-Cl showed slightly better antimicrobial activities compared to their inert analogues, $\mathrm{Rubb}_{7}$ and $\mathrm{Rubb}_{12}$. Conversely, $\mathrm{Rubb}_{16}$-Cl displayed slightly lower activity than Rubb ${ }_{16}$. Interestingly, Rubb $b_{7}-\mathrm{Cl}$ and $\mathrm{Rubb}_{12}-\mathrm{Cl}$ show better activities against the two Gram-negative species $E$. coli and $P$. aeruginosa than $\mathrm{Rubb}_{7}$ and $\mathrm{Rubb}_{12}$, respectively. Particularly noteworthy is the activity of $\mathrm{Rubb}_{7}-\mathrm{Cl}$ against $E$. coli compared to the Grampositive species $S$. aureus and MRSA: $\mathrm{Rubb}_{7}-\mathrm{Cl}$ is eight- and sixteen-fold more active towards $E$. coli than against $S$. aureus and MRSA, respectively. This preferential activity towards a Gram-negative species is very unusual for metal-based antimicrobial agents.

\section{Cytotoxicity against eukaryotic cells and selective activity}

To further evaluate the potential of the ruthenium complexes as antimicrobial agents, an understanding of their cytotoxicity towards mammalian cells is necessary. The cytotoxicities of the ruthenium complexes against the kidney cell lines BHK and HEK-293 were determined for incubation times of 24 hours. As there were no differences in the cytotoxicities (within experimental error) between the $\Delta-\mathrm{Rubb}_{n}-\mathrm{Cl}$ and the rac- $\mathrm{Rubb}_{n}$-Cl complexes in preliminary experiments, the rac$\mathrm{Rubb}_{n}$-Cl complexes were used to determine the 24-hour $\mathrm{IC}_{50}$ values. The $24 \mathrm{~h}-\mathrm{IC}_{50}$ values of the $\mathrm{Rubb}_{n}-\mathrm{Cl}$ and $\mathrm{Rubb}_{n}$ complexes are summarised in Table 2 .

Generally, the complexes with a longer linking chain were

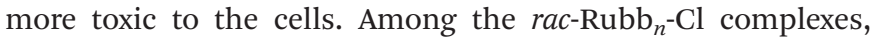
$\mathrm{Rubb}_{16}-\mathrm{Cl}$ was the most toxic complex towards BHK and HEK-293 cells. In contrast, $\mathrm{Rubb}_{7}-\mathrm{Cl}$ was nontoxic $(>200 \mu \mathrm{M})$ towards BHK but showed moderate cytotoxicity towards HEK-293, while Rubb $_{12}$-Cl showed similar cytotoxicity towards both cell lines. These observations suggest that the linking chain length plays an important role in their cytotoxicities. The inert complexes $\Delta \Delta-\mathrm{Rubb}_{12}$ and $\Delta \Delta-\mathrm{Rubb}_{16}$ also showed the same trend with $\Delta \Delta-\mathrm{Rubb}_{16}$ being more toxic than $\Delta \Delta-\mathrm{Rubb}_{12}$.

The good antimicrobial activity of the ruthenium complexes suggests they may have potential as antimicrobial agents.

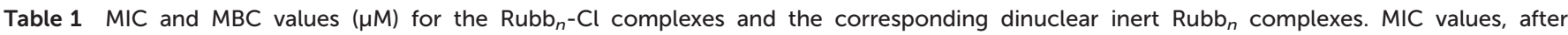
14-16 hours of incubation, were determined as $\mathrm{mg} \mathrm{L}^{-1}$ but converted to $\mu \mathrm{M}$ for direct comparison with the $\mathrm{IC}_{50}$ data obtained with eukaryotic cells

\begin{tabular}{|c|c|c|c|c|c|c|c|c|}
\hline \multirow[b]{2}{*}{ Complexes } & \multicolumn{2}{|c|}{ S. aureus } & \multicolumn{2}{|c|}{ MRSA } & \multicolumn{2}{|c|}{ E. coli } & \multicolumn{2}{|c|}{ P. aeruginosa } \\
\hline & MIC & $\mathrm{MBC}$ & MIC & MBC & MIC & MBC & MIC & MBC \\
\hline$\Delta$-Rubb ${ }_{12}-\mathrm{Cl}$ & 0.7 & 0.7 & 0.7 & 1.4 & 0.7 & 0.7 & 11.2 & 11.2 \\
\hline$\Delta-\mathrm{Rubb}_{16}-\mathrm{Cl}$ & 0.7 & 0.7 & 1.4 & 1.4 & 2.7 & 2.7 & 43.2 & 43.2 \\
\hline$\Delta \Delta-\mathrm{Rubb}_{7}$ & 10.7 & 21.3 & 10.7 & 21.3 & 10.7 & 10.7 & 85.3 & $>85$ \\
\hline$\Delta \Delta-\mathrm{Rubb}_{12}$ & 0.7 & 1.3 & 0.7 & 1.3 & 1.3 & 1.3 & 20.4 & 20.4 \\
\hline
\end{tabular}


Table $224 \mathrm{~h}-\mathrm{IC}_{50}$ values $(\mu \mathrm{M})$ of the ruthenium complexes against BHK and HEK-293 cells, and selectivity indices $\mathrm{SI}=24 \mathrm{~h}-\mathrm{IC}{ }_{50} / \mathrm{MIC}$, of the ruthenium complexes between kidney cells (BHK and HEK-293) and two bacterial strains (S. aureus and E. coli)

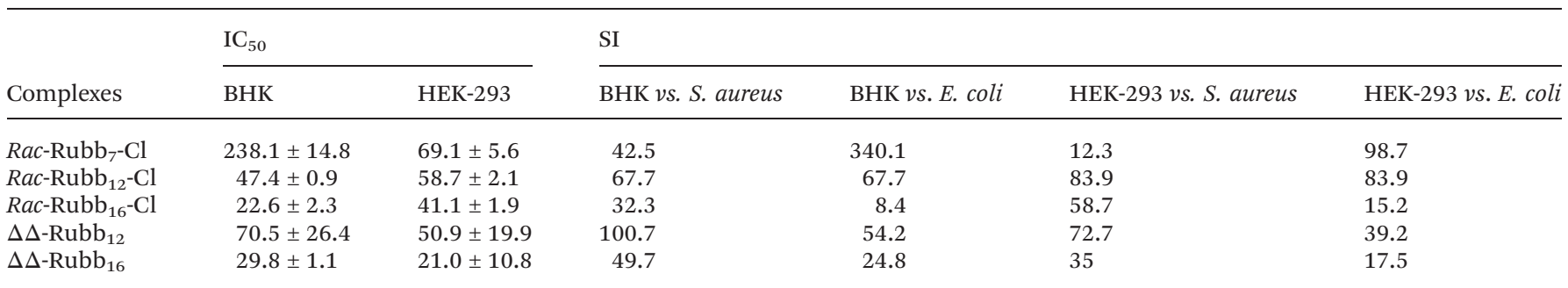

However, to be clinically useful as antimicrobial agents, it is desirable that the compounds exhibit significantly greater toxicity towards bacterial cells than mammalian cells. Table 2 also summarises the selectivity indices (SI, $24 \mathrm{~h}-\mathrm{IC}_{50} / \mathrm{MIC}$ ) between the BHK and HEK-293 cell lines and the Gram-positive bacterium $S$. aureus and the Gram-negative species $E$. coli. In general, the SI values demonstrated that all the ruthenium complexes were more toxic against bacterial cells than eukaryotic cells, with the SI values ranging from 8-340. Noticeably, $\mathrm{Rubb}_{7}-\mathrm{Cl}$ displayed the highest SI values for both BHK and HEK-293 cells against $E$. coli. Of particular note, the SI value of 340 between BHK and E. coli was at least five-times higher than with the other complexes. By contrast, $\mathrm{Rubb}_{12}-\mathrm{Cl}$ showed similar selectivity towards $S$. aureus and E. coli, compared to both kidney cell lines. The inert complex Rubb ${ }_{12}$ displayed a better selectivity for $S$. aureus than $E$. coli against both kidney cell lines. Taken together, $\mathrm{Rubb}_{12}-\mathrm{Cl}$ exhibited the best overall selectivity (but only marginally better than $\mathrm{Rubb}_{12}$ ), while $\mathrm{Rubb}_{7}-\mathrm{Cl}$ showed the best selectivity towards the Gramnegative E. coli.

The liver cell line HepG2 was chosen to determine the cytotoxicities of the ruthenium complexes in liver cells. The cytotoxicities of the ruthenium complexes against HepG2 cells were determined after a 24 -hour incubation, and the results are summarised in Table 3. The HepG2 cells were more susceptible than the kidney cells to $\mathrm{Rubb}_{7}-\mathrm{Cl}$ and $\mathrm{Rubb}_{12}-\mathrm{Cl}$, but were more resistant to $\mathrm{Rubb}_{16}$-Cl. Interestingly, and unlike what was observed with the BHK and HEK-293 cells, the cytotoxicities of the $\mathrm{Rubb}_{n}$-Cl complexes decreased with increasing

Table $324 \mathrm{~h}-\mathrm{IC} \mathrm{C}_{50}$ values $(\mu \mathrm{M})$ of the ruthenium complexes against HepG2 cells, and selectivity indices (SX) of the ruthenium complexes compared to the kidney cell lines. SX is defined as the ratio of the $\mathrm{IC}_{50}$ against BHK or HEK-293 cells divided by the $\mathrm{IC}_{50}$ against the HepG2 cell line

\begin{tabular}{|c|c|c|c|}
\hline \multirow[b]{2}{*}{ Complexes } & \multirow{2}{*}{$\begin{array}{l}\text { IC }_{50} \\
\text { HepG2 }\end{array}$} & \multicolumn{2}{|l|}{ SX } \\
\hline & & BHK vs. HepG2 & HEK-293 vs. HepG2 \\
\hline 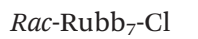 & $3.7 \pm 0.7$ & 64.4 & 18.7 \\
\hline Rac-Rubb ${ }_{12}-\mathrm{Cl}$ & $24.3 \pm 3.9$ & 2.0 & 2.4 \\
\hline Rac-Rubb ${ }_{16}-\mathrm{Cl}$ & $52.0 \pm 2.9$ & 0.4 & 0.8 \\
\hline$\Delta \Delta-\mathrm{Rubb}_{12}$ & $61.7 \pm 5.5$ & 1.1 & 0.8 \\
\hline$\Delta \Delta-\mathrm{Rubb}_{16}$ & $41.5 \pm 2.9$ & 0.7 & 0.5 \\
\hline
\end{tabular}

chain length in the $\mathrm{bb}_{n}$ ligand. Surprisingly, $\mathrm{Rubb}_{7}-\mathrm{Cl}$ was the most cytotoxic of all the ruthenium complexes assayed against the HepG2 cells, with the $24 \mathrm{~h}-\mathrm{IC}_{50}$ being $3.7 \mu \mathrm{M}$. The comparative selectivities between the two kidney cell lines and the HepG2 cell line were calculated for each of the ruthenium complexes and the results are summarised in Table $3 . \mathrm{Rubb}_{7}-\mathrm{Cl}$ clearly exhibited significantly higher toxicity towards the HepG2 cell line - compared to the two kidney cell lines - than did the other ruthenium complexes. Although the relative difference was much smaller, $\mathrm{Rubb}_{12}-\mathrm{Cl}$ was the only other complex to show some preferential toxicity to the HepG2 cells.

\section{Cellular localisation of $r a c-\mathrm{Rubb}_{n}$-Cl complexes in HepG2 cells}

Cellular localisation patterns are important in unravelling the mechanism of cytotoxicity for any drug. Therefore, the intrinsic phosphorescence properties of the ruthenium complexes were used to study their cellular localisation by laser-scanning confocal microscopy. To achieve this, the ruthenium complex phosphorescence patterns were overlaid with the fluorescence patterns of DNA/RNA/mitochondria-specific stains in colabelling experiments.

As shown in Fig. 7, the rac-Rubb ${ }_{n}$-Cl complexes showed similar nucleolus localisation to that previously reported for the inert $\mathrm{Rubb}_{n}$ complexes. ${ }^{22}$ The nucleolus of HepG2 cells were stained by $\mathrm{Rubb}_{n}$-Cl and SYTO 9. In addition to SYTO 9-stained rRNA, the most toxic complex $\mathrm{Rubb}_{7}-\mathrm{Cl}$ also showed localisation with DAPI-stained DNA. By contrast, $\mathrm{Rubb}_{12}-\mathrm{Cl}$ and $\mathrm{Rubb}_{16}$-Cl overlaid more with SYTO 9-stained rRNA in the nucleolus, and less with DAPI-stained DNA. In particular, $\mathrm{Rubb}_{12}$-Cl was exclusively localised in the nucleolus. These results suggest that $\mathrm{Rubb}_{12}-\mathrm{Cl}$ and $\mathrm{Rubb}_{16}-\mathrm{Cl}$ have greater selectivity for rRNA, compared to DNA, than does $\mathrm{Rubb}_{7}-\mathrm{Cl}$.

BHK cells incubated with $\mathrm{Rubb}_{7}-\mathrm{Cl}$ at a concentration of $100 \mu \mathrm{M}$ (approx. $50 \%$ of the $\mathrm{IC}_{50}$ ) for 20 hours are shown in Fig. 8. The Rubb ${ }_{7}-\mathrm{Cl}$ phosphorescence is observed throughout the cytoplasm and in the nucleus; however, within the nucleus the phosphorescence was mainly in the nucleolus, with little overlay with the DAPI-stained DNA. When BHK cells were incubated with $\mathrm{Rubb}_{7}-\mathrm{Cl}$ at a concentration of $50 \mu \mathrm{M}$ for 20 hours, almost no phosphorescence was observed in the nucleus, with only relatively weak accumulation of the ruthenium complex in the cytoplasm (see Fig. 9). 
a

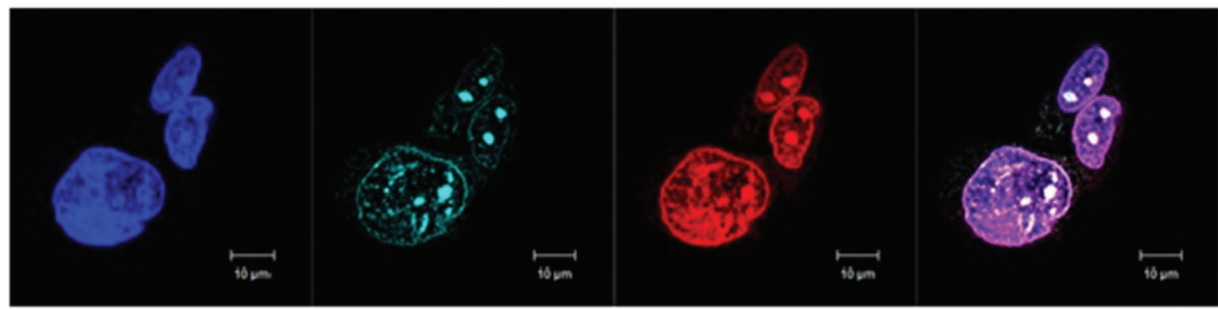

b

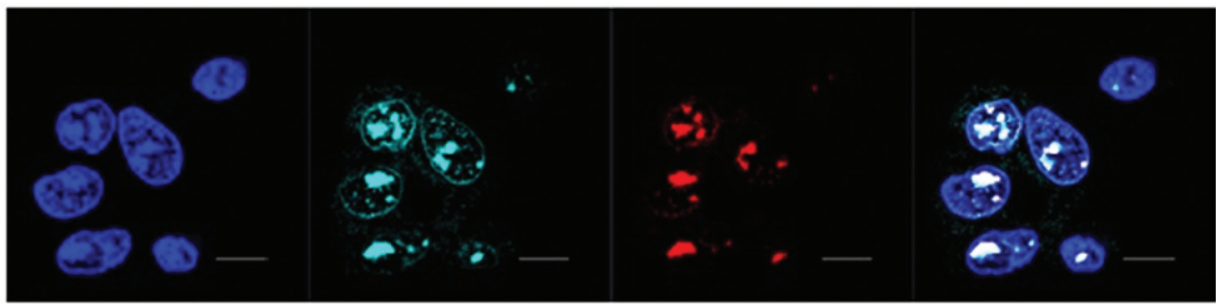

c

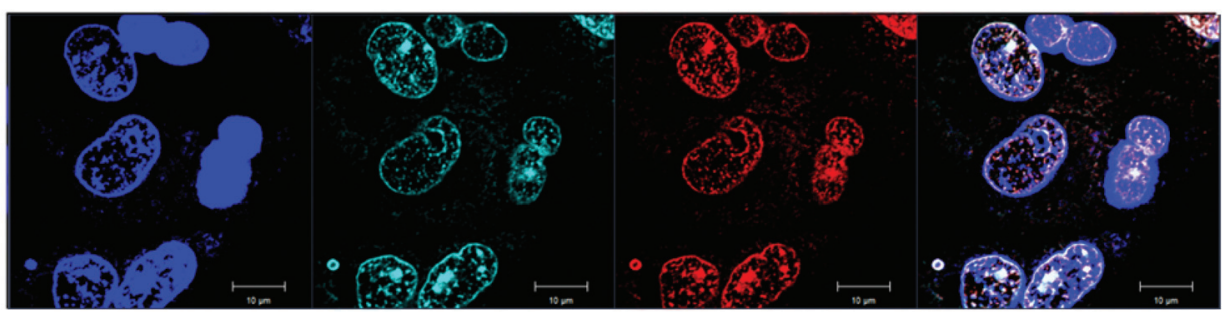

Fig. 7 Rac-Rubb ${ }_{n}-\mathrm{Cl}$ (red, $\mathrm{a}=\mathrm{Rubb}_{7}-\mathrm{Cl}, \mathrm{b}=\mathrm{Rubb}_{12}-\mathrm{Cl}, \mathrm{c}=\mathrm{Rubb}_{16}-\mathrm{Cl} ; 5 \mu \mathrm{M}, 20$ hour incubation) co-localisation in HepG2 cells with DAPI (blue)

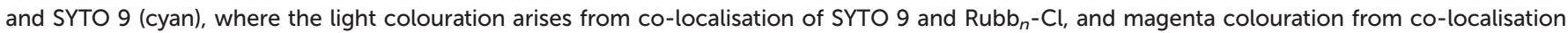
of DAPI and ruthenium complexes. Scale bar $=10 \mu \mathrm{m}$.

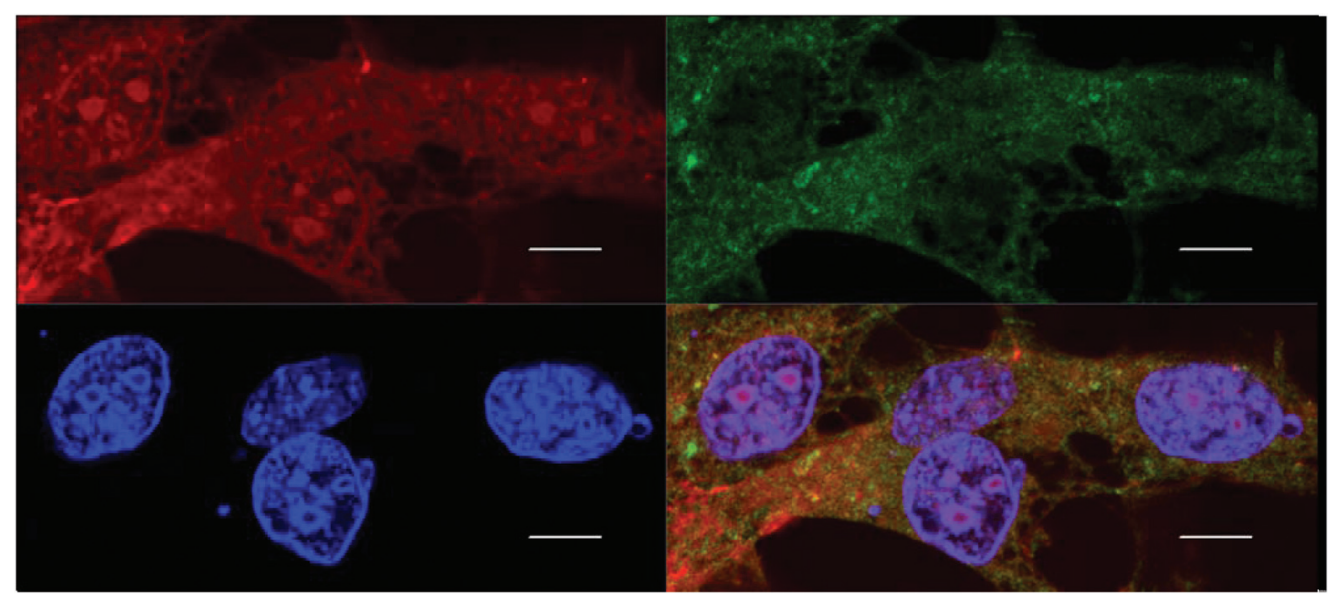

Fig. 8 Rac-Rubb $-\mathrm{Cl}$ (red; $100 \mu \mathrm{M} ; 20$ hour incubation) co-localisation in BHK cells with DAPI (blue) and Mitotracker Green (green), where the light colouration arises from co-localisation of Mitotracker Green and $\mathrm{Rubb}_{7}-\mathrm{Cl}$, and magenta coloration from co-localisation of DAPI and Rubb $\mathrm{C}_{7} \mathrm{Cl}$. Scale bar $=10 \mu \mathrm{m}$.

\section{Discussion}

We have previously demonstrated that the dinuclear ruthenium complexes $\mathrm{Rubb}_{n}$ and Cl-Rubb ${ }_{n}$-Cl have good antimicrobial activity. ${ }^{18,25}$ As would be expected, significant differences in activity are observed upon changes to the total charge, charge separation and lipophilicity of the ruthenium complexes. To further investigate the interplay between these para- meters, we have in this study synthesised and analysed the antimicrobial activities of the $\mathrm{Rubb}_{n}$-Cl series of complexes. The results demonstrate that the $\mathrm{Rubb}_{n}$-Cl complexes also have good antimicrobial activity and are bactericidal, with the most active complex against both Gram-positive and Gramnegative strains being Rubb $_{12}$-Cl. Similarly to what was observed for the Rubb ${ }_{n}$ complexes, the $\mathrm{Rubb}_{n}$-Cl complexes were considerably more toxic to bacterial cells than towards 


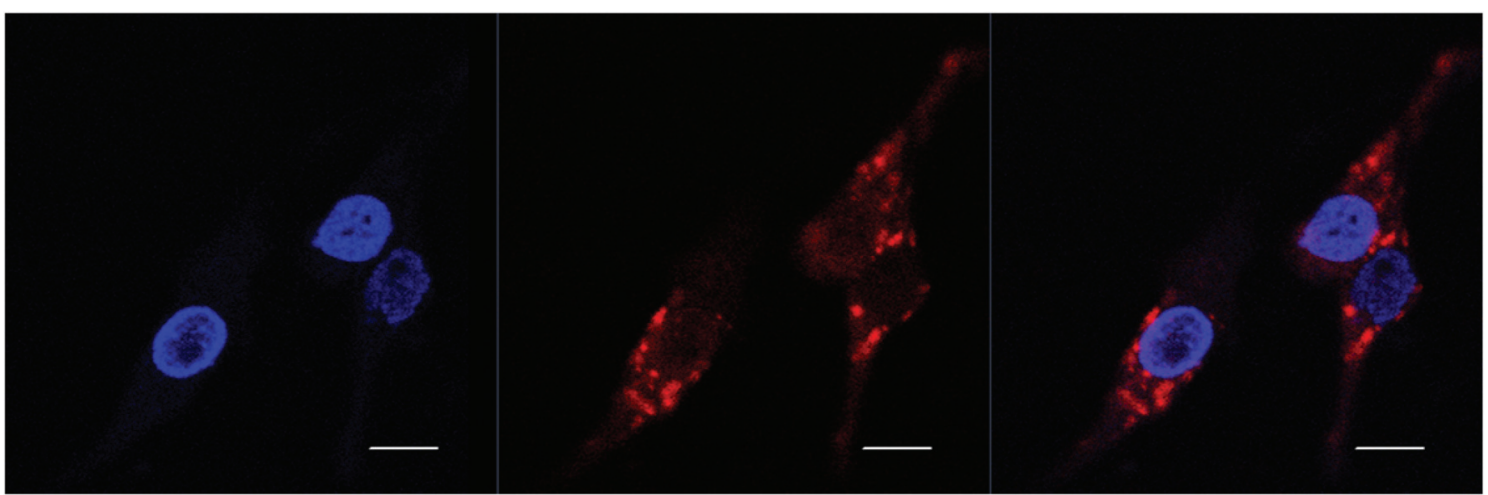

Fig. 9 DAPI (blue) and rac-Rubb $-\mathrm{Cl}$ (red; $50 \mu \mathrm{M} ; 20$ hour incubation) localisation in BHK cells. Scale bar $=10 \mu \mathrm{m}$.

eukaryotic cells. With the exception of $P$. aeruginosa, $\mathrm{Rubb}_{12}-\mathrm{Cl}$ was 35- to 84-times more toxic to the bacteria used in this study than to BHK, HEK-293 or HepG2 cells. However, and perhaps of greatest interest, was the observed toxicity profile of $\mathrm{Rubb}_{7}-\mathrm{Cl}$. Rubb $\mathrm{R}_{7}-\mathrm{Cl}$ was eight- to sixteen-fold more active against $E$. coli than the Gram-positive species, and even more significantly, $\mathrm{Rubb}_{7}-\mathrm{Cl}$ was vastly less toxic towards BHK cells but considerably more toxic towards HepG2 cells than Rubb ${ }_{12}-\mathrm{Cl}$, $\mathrm{Rubb}_{16}-\mathrm{Cl}, \mathrm{Rubb}_{12}$ and Rubb ${ }_{16}$.

The preferential activity of $\mathrm{Rubb}_{7}-\mathrm{Cl}$ towards Gram-negative E. coli over the Gram-positive species $S$. aureus and MRSA is very unusual for a metal-based antimicrobial agent. A few metal complexes have shown higher activity against Gramnegative than Gram-positive bacteria. For example, two helicate-like dinuclear iron complexes showed two-fold higher activity against $E$. coli than $S$. aureus, ${ }^{35}$ and a $\left[\mathrm{Ru}_{2} \mathrm{~L}_{3}\right]^{4+}$ triplystranded helicate complex also showed higher activity towards $E$. coli than $S$. aureus, but the activities were modest. ${ }^{36}$ However, most metal complexes have shown greater antimicrobial activity against Gram-positive species than Gram-negative species. ${ }^{9-11,18-25,37,38}$

The $\mathrm{Rubb}_{n}$-Cl complexes also showed a different pattern of activities to the $\mathrm{Rubb}_{n}$ and $\mathrm{Cl}-\mathrm{Rubb}_{n}-\mathrm{Cl}$ complexes. Against the Gram-positive bacteria, $\mathrm{Rubb}_{12}-\mathrm{Cl}$ and $\mathrm{Rubb}_{16}-\mathrm{Cl}$ were of equal activity and considerably more active than $\mathrm{Rubb}_{7}-\mathrm{Cl}$. However, for the Gram-negative species, $\mathrm{Rubb}_{7}-\mathrm{Cl}$ and $\mathrm{Rubb}_{12}$-Cl were of equal activity and were considerably more active than Rubb ${ }_{16}-\mathrm{Cl}$. For the $\mathrm{Rubb}_{n}$ and $\mathrm{Cl}-\mathrm{Rubb}_{n}$-Cl complexes, the same pattern of activities was observed for all bacteria. For the Rubb complexes, the order of the activities across the four bacteria was $\mathrm{Rubb}_{16} \geq \mathrm{Rubb}_{12}>\mathrm{Rubb}_{7}$; while for the Cl-Rubb${ }_{n}$-Cl

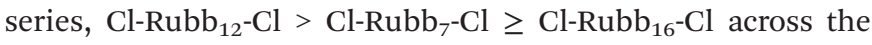
bacteria. Although the differences are relatively small, $\mathrm{Rubb}_{12}-\mathrm{Cl}$ showed the best activity profile against the four bacterial species used in this study compared to any of the $\mathrm{bb}_{n}$-linked ruthenium complexes that have been previously reported. ${ }^{18-25}$

Cytotoxicity assays against the kidney cell lines BHK and HEK-293 and the liver cell line HepG2 were carried out to estimate the toxicity of the $\mathrm{Rubb}_{n}$-Cl complexes towards mammalian organ cells. In BHK and HEK-293 cells, the 24 h- $\mathrm{IC}_{50}$ values for the $\mathrm{Rubb}_{n}$-Cl series decreased with the increasing number of methylene groups in the $\mathrm{bb}_{n}$ ligand. A similar trend was observed for the Rubb ${ }_{n}$ complexes. These results suggest that cellular uptake is the key parameter, at least to a first approximation, with the uptake being correlated to the lipophilicity of the ruthenium complex. However, in HepG2 cells the least lipophilic complex Rubb $-\mathrm{Cl}$ exhibited the highest cytotoxicity while the most lipophilic complex $\mathrm{Rubb}_{16}-\mathrm{Cl}$ was the least toxic. Hence, it is probable that while lipophilicity is important, at least in terms of cellular uptake, there are other factors to be considered. Compared with healthy cells, the cancer cell outer membrane leaflet contains three- to ninetimes more negatively-charged lipids and greater levels of negatively-charged $O$-glycosylated mucins. ${ }^{39-41}$ In contrast, in non-cancerous cells the membrane is largely occupied by zwitterionic phospholipids, with negligible or weak negative charge. ${ }^{42,43}$ In addition, the increased number of microvilli on cancer cells, which lead to an increase in cell surface area, may also enhance their susceptibility. ${ }^{44,45}$ Therefore, the cellular uptake of the polycationic ruthenium complexes may be less affected by lipophilicity in cancer cell lines compared with healthy cells.

Intracellular localisation could also be an important aspect of cytotoxicity. Confocal microscopy was used to determine the cellular localisation of the $\mathrm{Rubb}_{n}$-Cl complexes in HepG2 cells. The $\mathrm{Rubb}_{n}$-Cl complexes preferentially accumulated in the nucleolus, while significant DNA binding was also observed at higher concentrations. The preference for rRNA is consistent with our previous studies on the localisation of Rubb 12 in BHK cells $^{22}$ and Rubb $_{16}$ in the ribosomes of E. coli. ${ }^{21}$ However, the $\mathrm{Rubb}_{n}$-Cl complexes showed differences in nuclear localisation in HepG2 cells based upon the length of the alkyl chain in the $\mathrm{bb}_{n}$ linking ligand. The least lipophilic complex $\mathrm{Rubb}_{7}-\mathrm{Cl}$ appeared to co-localise to a higher degree with DNA, while the other two complexes, particularly $\mathrm{Rubb}_{12}-\mathrm{Cl}$, showed greater accumulation in the nucleolus. The effect of lipophilicity on the cellular localisation of ruthenium complexes has been previously reported. Lincoln, Nordén and co-workers found the length of an alkyl chain in a dppz-based complex (dppz = dipyrido[3,2- $\left.a: 2^{\prime}, 3^{\prime}-c\right]$ phenazine) had a significant effect on the 
localisation pattern - the least lipophilic complex was found to stain nuclear DNA, the most lipophilic complex preferably stained cellular membranes, whereas the derivative of intermediate lipophilicity selectively stained the RNA-rich nucleoli. ${ }^{46}$ Furthermore, Thomas and co-workers demonstrated that the dinuclear complex $\left[\left\{\mathrm{Ru}(\mathrm{phen})_{2}\right\}_{2}\{\mu \text {-tpphz }\}\right]^{4+}$ (where tpphz = tetrapyridophenazine) localised in the nucleus, while the more lipophilic 4,7-diphenyl-1,10-phenanthroline analogue $\left[\left\{\mathrm{Ru}(\mathrm{DIP})_{2}\right\}_{2}\{\mu \text {-tpphz }\}\right]^{4+}$ localised in the endoplasmic reticulum. ${ }^{47,48}$ While other factors are yet to be examined, the greater level of DNA localisation in HepG2 by $\mathrm{Rubb}_{7}-\mathrm{Cl}$, compared to $\mathrm{Rubb}_{12}-\mathrm{Cl}$ and $\mathrm{Rubb}_{12}$, could be related to its higher cytotoxicity against this cell line. Consistent with this proposal was the observed low level of DNA binding, compared to that in the nucleolus and cytoplasm, by $\mathrm{Rubb}_{7}-\mathrm{Cl}$ in $\mathrm{BHK}$ cells at concentrations considerably higher than the 24 h- $\mathrm{IC}_{50}$ determined against HepG2 cells.

In conclusion, a new class of dinuclear ruthenium complexes, $\mathrm{Rubb}_{n}-\mathrm{Cl}$, has been synthesised and characterised. These ruthenium complexes exhibited good antimicrobial activities; and interestingly, showed relatively better activity towards Gram-negative bacteria, (compared to Gram-positive species) than previously reported ruthenium complexes linked by the $\mathrm{bb}_{n}$ ligand. In addition, the $\mathrm{Rubb}_{n}-\mathrm{Cl}$ complexes were considerably less toxic to eukaryotic cells, compared to bacteria, with $\mathrm{Rubb}_{7}-\mathrm{Cl}$ showing striking differences in cytotoxicity between the eukaryotic cell lines. It is possible that $\mathrm{Rubb}_{7}-\mathrm{Cl}$ could become a new lead compound for metal-based anticancer or antimicrobial agents.

\section{Acknowledgements}

F. R. K. acknowledges the award of a Visiting Professorship from UNSW Canberra.

\section{References}

1 J. H. Powers, Clin. Microbiol. Infect., 2004, 10(Suppl 4), 23.

2 E. Wong and C. M. Giandomenico, Chem. Rev., 1999, 99, 2451.

3 B. Nordén, P. Lincoln, B. Akerman and E. Tuite, Met. Ions Biol. Syst., 1996, 33, 177.

4 C. Metcalfe and J. A. Thomas, Chem. Soc. Rev., 2003, 32, 215.

5 B. M. Zeglis, V. C. Pierre and J. K. Barton, Chem. Commun., 2007, 4565.

6 M. R. Gill and J. A. Thomas, Chem. Soc. Rev., 2012, 41, 3179.

7 A. D. Richards, A. Rodger, M. J. Hannon and A. Bolhuis, Int. J. Antimicrob. Agents, 2009, 33, 469.

8 N. S. Ng, P. Leverett, D. E. Hibbs, Q. Yang, J. C. Bulanadi, M. J. Wu and J. R. Aldrich-Wright, Dalton Trans., 2013, 42, 3196.
9 F. P. Dwyer, E. C. Gyarfas, W. P. Rogers and J. H. Koch, Nature, 1952, 170, 190.

10 F. P. Dwyer, I. K. Reid, A. Shulman, G. M. Laycock and S. Dixson, Aust. J. Exp. Biol. Med. Sci., 1969, 47, 203.

11 A. Bolhuis, L. Hand, J. E. Marshall, A. D. Richards, A. Rodger and J. Aldrich-Wright, Eur. J. Pharm. Sci., 2011, 42, 313.

12 C. S. Devi, D. A. Kumar, S. S. Singh, N. Gabra, N. Deepika, Y. P. Kumar and S. Satyanarayana, Eur. J. Med. Chem., 2013, 64, 410.

13 K. A. Kumar, K. L. Reddy, S. Vidhisha and S. Satyanarayana, Appl. Organomet. Chem., 2009, 23, 409.

14 N. H. Khan, N. Pandya, R. I. Kureshy, S. H. R. Abdi, S. Agrawal, H. C. Bajaj, J. Pandya and A. Gupte, Spectrochim. Acta, Part A, 2009, 74, 113.

15 P.-L. Lam, G.-L. Lu, K.-M. Hon, K.-W. Lee, C.-L. Ho, X. Wang, J. C.-O. Tang, K.-H. Lam, R. S.-M. Wong, S. H.L. Kok, Z.-X. Bian, H. Li, K. K.-H. Lee, R. Gambari, C.-H. Chui and W.-Y. Wong, Dalton Trans., 2014, 43, 3949.

16 N. Thilagavathi, A. Manimaran and C. Jayabalakrishnan, J. Coord. Chem., 2010, 63, 1252.

17 C. S. Allardyce, P. J. Dyson, D. J. Ellis, P. A. Salter and R. Scopelliti, J. Organomet. Chem., 2003, 668, 35.

18 F. Li, Y. Mulyana, M. Feterl, J. M. Warner, J. G. Collins and F. R. Keene, Dalton Trans., 2011, 40, 5032.

19 F. Li, M. Feterl, Y. Mulyana, J. M. Warner, J. G. Collins and F. R. Keene, J. Antimicrob. Chemother., 2012, 67, 2686.

20 F. Li, M. Feterl, J. M. Warner, F. R. Keene and J. G. Collins, J. Antimicrob. Chemother., 2013, 68, 2825.

21 F. Li, E. J. Harry, A. L. Bottomley, M. D. Edstein, G. W. Birrell, C. E. Woodward, F. R. Keene and J. G. Collins, Chem. Sci., 2014, 5, 685.

22 X. Li, A. K. Gorle, T. D. Ainsworth, K. Heimann, C. E. Woodward, J. G. Collins and F. R. Keene, Dalton Trans., 2015, 44, 3594.

23 F. Li, J. G. Collins and F. R. Keene, Chem. Soc. Rev., 2015, 44, 2529.

24 A. K. Gorle, M. Feterl, J. M. Warner, L. Wallace, F. R. Keene and J. G. Collins, Dalton Trans., 2014, 43, 16713.

25 M. Pandrala, F. Li, M. Feterl, Y. Mulyana, J. M. Warner, L. Wallace, F. R. Keene and J. G. Collins, Dalton Trans., 2013, 42, 4686.

26 Y. Mulyana, G. Collins and R. Keene, J. Inclusion Phenom. Macrocyclic Chem., 2011, 71, 371.

27 J. L. Morgan, C. B. Spillane, J. A. Smith, D. P. Buck, J. G. Collins and F. R. Keene, Dalton Trans., 2007, 4333.

28 P. A. Adcock, F. R. Keene, R. S. Smythe and M. R. Snow, Inorg. Chem., 1984, 23, 2336.

29 X. Hua and A. von Zelewsky, Inorg. Chem., 1995, 34, 5791.

30 D. J. States, R. A. Haberkorn and D. J. Ruben, J. Magn. Reson., 1982, 48, 286.

31 H. R. Hypercube Inc., Gainesville, FL, USA, 2005.

32 British Society for Antimicrobial Chemotherapy Working Party, J. Antimicrob. Chemother., 1991, 27,22 . 
33 M. Motyl, K. Dorso, J. Barrett and R. Giacobbe, in Current Protocols in Pharmacology, John Wiley \& Sons, Inc., 2005, pp. 13A.3.1-13A.3.22.

34 J. O'Brien, I. Wilson, T. Orton and F. Pognan, Eur. J. Biochem., 2000, 267, 5421.

35 S. E. Howson, A. Bolhuis, V. Brabec, G. J. Clarkson, J. Malina, A. Rodger and P. Scott, Nat. Chem., 2011, 4, 31.

36 S. V. Kumar, W. K. C. Lo, H. J. L. Brooks and J. D. Crowley, Inorg. Chim. Acta, 2015, 425, 1.

37 N. S. Ng, P. Leverett, D. E. Hibbs, Q. Yang, J. C. Bulanadi, M. Jie Wu and J. R. Aldrich-Wright, Dalton Trans., 2013, 42, 3196.

38 A. Srishailam, Y. P. Kumar, N. M. D. Gabra, P. V. Reddy, N. Deepika, N. Veerababu and S. Satyanarayana, J. Fluoresc., 2013, 23, 897.

39 J. S. Mader and D. W. Hoskin, Expert Opin. Inves. Drugs, 2006, 15, 933.
40 N. Papo and Y. Shai, Cell. Mol. Life Sci., 2005, 62, 784.

41 R. F. Zwaal and A. J. Schroit, Blood, 1997, 89, 1121.

42 I. L. Ang, T. C. W. Poon, P. B. S. Lai, A. T. C. Chan, S.-M. Ngai, A. Y. Hui, P. J. Johnson and J. J. Y. Sung, J. Proteome Res., 2006, 5, 2691.

43 S. Riedl, D. Zweytick and K. Lohner, Chem. Phys. Lipids, 2011, 164, 766.

44 N. Papo and Y. Shai, Biochemistry, 2003, 42, 9346.

45 S. C. Chan, L. Hui and H. M. Chen, Anticancer Res., 1998, 18, 4467.

46 M. Matson, F. R. Svensson, B. Nordén and P. Lincoln, J. Phys. Chem. B, 2011, 115, 1706.

47 M. R. Gill, J. Garcia-Lara, S. J. Foster, C. Smythe, G. Battaglia and J. A. Thomas, Nat. Chem., 2009, 1, 662.

48 M. R. Gill, D. Cecchin, M. H. Walker, R. S. Mulla, G. Battaglia, C. Smythe and J. A. Thomas, Chem. Sci., 2013, 4,4512 . 